\title{
14. FORAMINIFERAL, LITHIC, AND ISOTOPIC CHANGES ACROSS FOUR MAJOR UNCONFORMITIES AT DEEP SEA DRILLING PROJECT SITE 548, GOBAN SPUR ${ }^{1}$
}

\author{
C. Wylie Poag and Leslie A. Reynolds, U.S. Geological Survey, Woods Hole \\ James M. Mazzullo, Texas A \& M University, College Station \\ and \\ Lloyd D. Keigwin, Jr., Woods Hole Oceanographic Institution, Woods Hole ${ }^{2}$
}

\begin{abstract}
Sediment samples taken at close intervals across four major unconformities (middle Miocene/upper Miocene, lower Oligocene/upper Oligocene, lower Eocene/upper Eocene, lower Paleocene/upper Paleocene) at DSDP-IPOD Site 548, Goban Spur, reveal that coeval biostratigraphic gaps, sediment discontinuities, and seismic unconformities coincide with postulated low stands of sea level. Foraminiferal, lithic, and isotopic analyses demonstrate that environments began to shift prior to periods of marine erosion, and that sedimentation resumed in the form of turbidites derived from nearby upper-slope sources. The unconformities appear to have developed where a water-mass boundary intersected the continental slope, rhythmically crossing the drill site in concert with sea-level rise and fall.
\end{abstract}

\section{INTRODUCTION}

Marine geologists have been intrigued by submarine unconformities ever since deep-sea drilling began to show that the stratigraphic record of the oceans is full of gaps (Berggren, 1969; Ewing et al., 1969; Pessagno, 1969). Several stratigraphic syntheses have demonstrated the repetitious and widespread occurrence of many of these gaps, and several of the major ones have been related to basic changes in deep-sea circulation and the composition of bottom waters (Rona, 1973; Moore and Heath, 1977; Moore et al., 1978; Thiede et al., 1980, 1981). Since the late 1970s, Peter R. Vail and his colleagues have emphasized the role of eustatic sea-level drops in creating erosional episodes of global scale along continental margins. These authors also have argued that many deep-sea unconformities are correlative with stratigraphic gaps on continental shelves, and that they can be linked to eustatic sea-level changes through global climatic fluctuations. (such as expansion and contraction of continental ice sheets; Vail et al., 1977, 1980; Vail and Todd, 1981). However, the linkage of deep-sea unconformities with sea-level changes has been challenged (Tucholke, 1981).

A major limiting factor in studying the properties and causes of deep-sea unconformities has been their propensity for eluding the core barrel. Seldom have wellpreserved unconformable contacts been recovered in DSDP cores. Leg 80 cores are unusual in this respect, for they contain a large number of undisturbed unconformable contacts. These contacts can be precisely placed in a biostratigraphic framework with calcareous nannofossils and planktonic foraminifers, and can be

\footnotetext{
${ }^{1}$ Graciansky, P. C. de, Poag, C. W., et al., Init. Repts. DSDP, 80: Washington (U.S. Govt, Printing Office).

2 Addresses: (Poag and Reynolds) U.S. Geological Survey, Woods Hole, MA; (Mazzullo) Texas A \& M University, College Station, TX; (Keigwin) Woods Hole Oceanographic Institution, Woods Hole, MA.
}

traced away from the boreholes on multichannel seismic reflection profiles. Several of the unconformities can be identified in all four cored holes of the Goban Spur transect.

This chapter presents the results of a pilot study to assess foraminiferal, lithic, and isotopic changes across the unconformities, to evaluate sample spacing, and to interpret the origins of the unconformities. In order to accomplish this assessment, we have chosen for study four clearly expressed unconformable contacts from the shallowest site (Site 548, $1246 \mathrm{~m}$ water depth, Figs. 1 and 2). Faunal and isotopic analyses were made on the same set of samples, but a different, less comprehensive set was used for the petrologic studies because of limitations on the number of samples allowed within the subject core intervals. We use the term unconformity in a broad sense to mean the physical expression of an interruption in depositional continuity.

\section{METHODS}

Calcareous nannofossil zonation provided by C. Müller (this volume) was used to estimate the duration of the hiatus at each unconformity. Samples for nannofossil analyses were taken as near the contacts as possible. For foraminiferal analyses, two to four samples of $\sim 20 \mathrm{~cm}^{3}$ volume were taken at varied intervals of 1 to $72 \mathrm{~cm}$ above and below the contacts. Estimated temporal sampling intervals varied from zero (abutting samples) to 12,800 yrs. Biostratigraphic zonation indicates, however, that the sedimentary section in and adjacent to Sections 548-28-5 and 548-28-6 is so abbreviated that we cannot estimate depositional rates and temporal sample intervals near this unconformity. We examined the $>74-\mu \mathrm{m}$ size fraction for the quantitative foraminiferal census, in which approximately 300 specimens were picked from aliquots to determine the relative abundances of genera and species.

In order to detect change in sediment source or transport history across the unconformities in Hole 548A, grain-size and clay-mineralogical analyses were conducted on splits of each sample. Direct grainsize measurements were made on thin-sectioned samples with an optical micrometer. Thin sections were placed under a microscope to which a high-resolution RCA television camera, capable of resolving objects less than $1 \mu \mathrm{m}$ in size, was attached. The microscope image was relayed to a high-resolution television monitor, at which point a calibrated scale 
was used to measure the long axes of 100 randomly chosen grains in each sample. Data from these measurements were stored and analyzed in a CROMENCO microcomputer.

For the X-ray analyses, each sample was ground to a powder with a mortar and pestle, placed in a test tube with approximately $10 \mathrm{ml}$ of distilled water and $1 \mathrm{ml}$ of ammonium hydroxide (a deflocculant), and agitated for one minute. After allowing the sediment to settle in the test tube for $20 \mathrm{~min}$., a slide was prepared by allowing $0.5 \mathrm{ml}$ of the uppermost part of this slurry to dry onto a petrographic glass slide. Xray diffraction patterns, using $\mathrm{Cu}-\mathrm{K}_{\alpha}$ radiation at scanning speeds of 1 to $20^{\circ}$ per min., were made of these slides; then each sample was successively saturated with ethylene glycol, heated to $400^{\circ} \mathrm{C}$ for $20 \mathrm{~min}$., and heated to $550^{\circ} \mathrm{C}$ for $20 \mathrm{~min}$., and X-rayed. Relative percentages of four clay groups-montmorillonite, illite, mixed-layer illite-montmorillonite, and kaolinite + chlorite-were determined using the method described by Biscaye (1964). It should be noted that the clay-group percentages are semiquantitative values; generally, the errors on such estimates are as high as $10 \%$.

For isotopic analyses we selected well-preserved Cibicides (Cibicidoides of some authors), chiefly of the $C$. ungerianus or $C$. wuellerstorfi morphology. Specimens of Cibicides were cleaned ultrasonically in methanol, dried, loaded into stainless steel carrying boats, crushed in methanol, and roasted in vacuo for one hour at $370^{\circ} \mathrm{C}$. Samples were dissolved in phosphoric acid at $50^{\circ} \mathrm{C}$, and $\mathrm{CO}_{2}$ and $\mathrm{H}_{2} \mathrm{O}$ were condensed by liquid nitrogen as they were produced. Sample gas was distilled using a propanol slush and compared to PDB on the basis of numerous analyses of the standard NBS-20, taking $\delta^{18} \mathrm{O}$ NBS $(\mathrm{PDB})=$ $-4.18 \%$ and $\delta^{13} \mathrm{C} \mathrm{NBS}(\mathrm{PDB})=-1.06 \%$. Analytical precision $(1 \sigma)$ of NBS analyses is $0.10 \%$ for $\delta^{18} \mathrm{O}$ and $0.07 \%$ for $\delta^{13} \mathrm{C}$.

\section{MIDDLE MIOCENE/UPPER MIOCENE UNCONFORMITY}

\section{Location, Age, Hiatus}

This unconformity is present at approximately $121 \mathrm{~cm}$ in Section 548-11-3 (Figs. 1 and 2). At the contact, nannofossil Zone NN11 (upper Miocene) overlies NN6 (lower/middle Miocene), indicating a hiatus of $\sim 6 \mathrm{~m}$.y. (for convenience in comparing with the Vail and Hardenbol [1979] sea-level curve, we use the time scale of Vail and Mitchum [1979]).

On the high-resolution seismic profile generated by Glomar Challenger, this unconformity is seen to truncate the middle Miocene strata updip from Site 548, where these strata are more completely represented (somewhat thicker; Fig. 3). Upper Miocene beds in turn downlap the unconformity just east of the site. On the multichannel seismic profile (Fig. 4), the details of truncation and downlap cannot be seen updip from the site, but downdip these relationships can be seen in the vicinity of the lenticular body between shot-points 1500 and 1600. Most of the deposition of the lenticular body (sediment drift?) took place in the early and middle Miocene before erosion produced this unconformity.

\section{Lithology}

\section{Visual Description}

Sediment above the contact is dark greenish gray (5GY $7 / 1$ ), firm, finely laminated mudstone (millimeter-scale laminae; Fig. 2). Below the contact, sediment is light greenish gray, silty, firm, homogeneous nannofossil chalk.

The contact, near the middle of a disturbed zone approximately $10 \mathrm{~cm}$ thick, is a distinct but irregular line separating the two dominant lithologies. Faint evidence of bioturbation is presert in the chalk below the contact. Light and dark laminations are present just above the contact, but there are no obviously reworked clasts of light sediment in the laminated strata; nor is there clear evidence of dark sediment filling burrows in the gray chalk. Because the core was disturbed, we recognize that some part of the section may be missing.

\section{Grain Size and Clay Mineralogy}

Median grain size does not change dramatically across the boundary (Table 1), but there is a steady upsection coarsening, from $6.042 \phi$ in the chalk below to $5.998 \phi$ in the disturbed zone to $5.827 \phi$ in the laminated mudstone.

Relative abundance of terrigenous clay minerals (kaolinite and chlorite) decreases from $19 \%$ in the undisturbed chalk to $7 \%$ in the disturbed zone and in the laminated mudstone (Table 2). Percentage of mixed-layer clays, on the other hand, increases upsection from 3$5 \%$ to $15 \%$ across the contact. The unconformity is clearly marked on the gamma-ray log by an upward shift of $\sim 20$ API units that reflects this increase in clay minerals.

\section{Isotopic Analysis}

Oxygen isotopic results from Core 548A-11 are the heaviest of the entire data set, and do not change significantly across the unconformity at $548 \mathrm{~A}-11-3,121 \mathrm{~cm}$ (Table 3, Fig. 5). On the other hand, $\delta^{13} \mathrm{C}$ values increase distinctly above the contact.

\section{Foraminiferal Analyses}

Several distinct changes in foraminiferal assemblages take place across the unconformity at $548 \mathrm{~A}-11-3,121 \mathrm{~cm}$. Among benthic foraminifers, Epistominella is clearly the predominant genus below the unconformity (Table 4). Above the unconformity, generic equitability increases. Cassidulina and Bolivina are most abundant in the first three samples above the contact, whereas Eponides is slightly more abundant in the highest sample. All these genera are typically predominant today in epibathyal depths (Pujos-Lamy, 1973), but the faunal shift across the contact is an indication of a substantial change in origin of the assemblage.

The number of genera decreases significantly just below the contact. It continues to decline slightly across the contact, and remains at approximately this lower value above the contact (Fig. 6). A similar pattern is formed by the plot of benthic percentage, except that an isolated higher value is present in Sample 548A-11-3, 111$115 \mathrm{~cm}$.

Abundance trends among several individual genera also display distinct changes across the contact. In particular, the benthic forms Epistominella and Bolivina decrease and increase, respectively, above the boundary. Among planktonic genera, Turborotalia, clearly predominant $(40-50 \%)$ below the contact, is severely reduced to $5 \%$ or less above the contact, having been replaced by Globigerina (Table 5; Fig. 6).

\section{Interpretation}

Foraminiferal, lithic, and isotopic records that we have examined across the middle Miocene/upper Miocene contact in Section 548A-11-3 indicate that a signifi- 


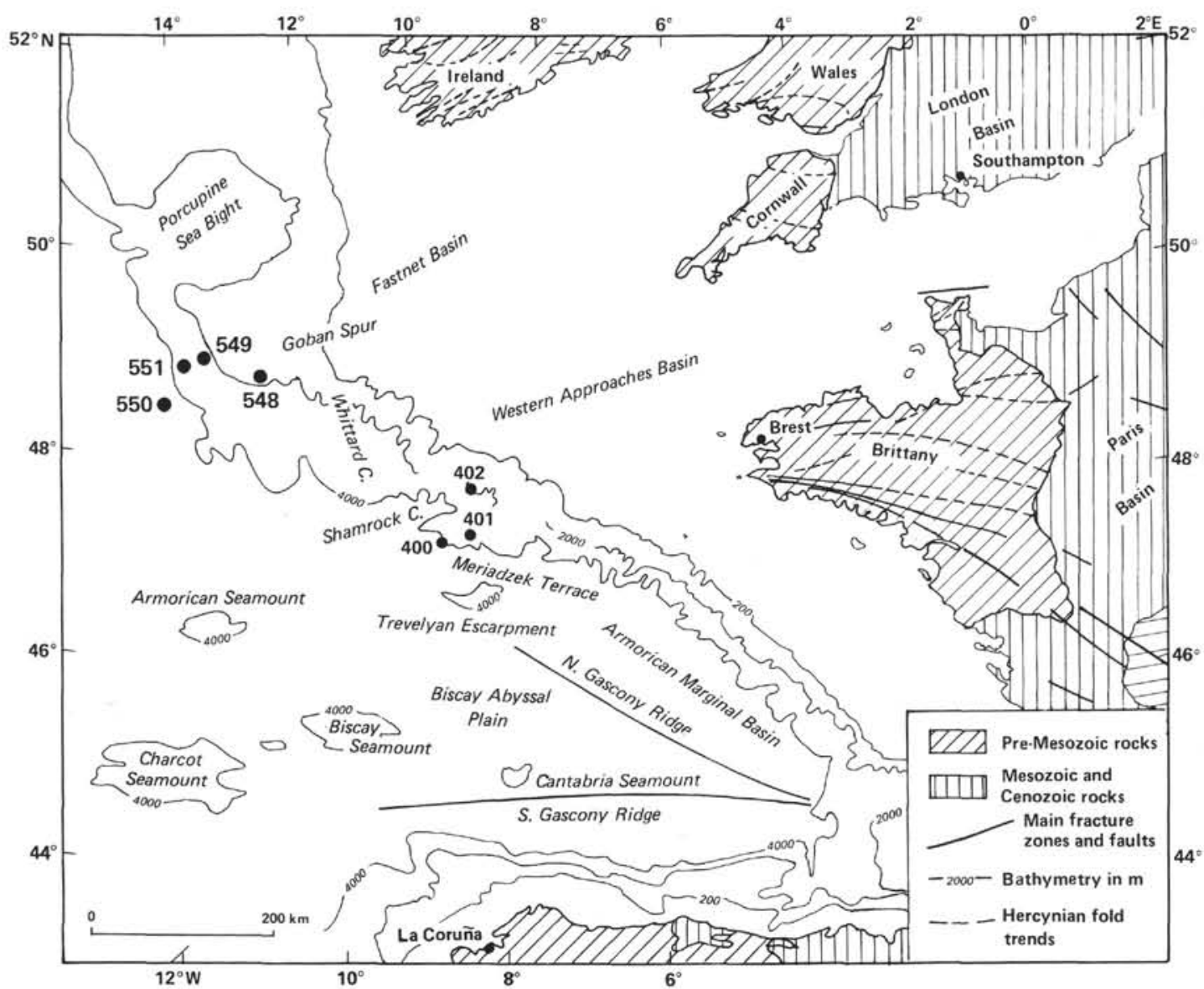

Figure 1. Map showing Goban Spur and DSDP-IPOD Leg 80 drill sites. (Bathymetry in meters.)

Table 1. Grain-size data, Site 548 (Hole 548A).

\begin{tabular}{|c|c|c|c|c|c|c|c|c|c|c|c|c|c|c|c|}
\hline \multirow{2}{*}{$\begin{array}{c}\text { Sample } \\
\text { (interval in } \mathrm{cm} \text { ) }\end{array}$} & \multicolumn{15}{|c|}{ Grain size $\mathrm{e}^{\mathrm{a}}$} \\
\hline & $2.5-3$ & $3-3.5$ & $3.5-4$ & $4-4.5$ & $4.5-5$ & $5-5: 5$ & $5.5-6$ & $6-6.5$ & $6.5-7$ & $7-7.5$ & $7.5-8$ & $8-8.5$ & $>8.5$ & Mean & S.D. \\
\hline $11-3,107-109$ & 0 & 0 & 1 & 9 & 17 & 15 & 12 & 14 & 21 & 5 & 4 & 0 & 2 & 5.827 & 1.088 \\
\hline $11-3,123-125$ & 0 & 2 & 0 & 8 & 7 & 7 & 12 & 27 & 29 & 4 & 4 & 0 & 0 & 5.998 & 0.984 \\
\hline $11-3,139-141$ & 0 & 6 & 8 & 2 & 2 & 6 & 12 & 18 & 34 & 2 & 8 & 2 & 0 & 6.042 & 1.257 \\
\hline $22-6,13-15$ & 0 & 0 & 8 & 9 & 0 & 11 & 10 & 10 & 13 & 11 & 14 & 7 & 7 & 6.446 & 1.553 \\
\hline $22-6,20-23$ & 0 & 0 & 0 & 0 & 0 & 4 & 2 & 9 & 19 & 11 & 22 & 15 & 18 & 7.534 & 1.047 \\
\hline $22-6,24-27$ & 0 & 0 & 0 & 8 & 4 & 0 & 2 & 13 & 17 & 7 & 15 & 8 & 26 & 7.409 & 1.592 \\
\hline $16-3,57-59$ & 10 & 0 & 9 & 15 & 8 & 4 & 17 & 13 & 22 & 0 & 2 & 0 & 0 & 5.202 & 1.386 \\
\hline $16-3,75-77$ & 0 & 0 & 4 & 0 & 2 & 0 & 14 & 11 & 27 & 8 & 13 & 13 & 8 & 6.925 & 1.274 \\
\hline $28-6,21-24$ & 0 & 8 & 11 & 9 & 9 & 1 & 10 & 7 & 11 & 6 & 13 & 13 & 2 & 5.914 & 1.793 \\
\hline $28-6,37-40$ & 0 & 0 & 0 & 0 & 14 & 4 & 10 & 2 & 12 & 14 & 24 & 8 & 12 & 7.017 & 1.250 \\
\hline
\end{tabular}

${ }^{a}$ Grain size is recorded as intervals in $\phi$ units; data are presented as \% grains in each interval.

Table 2. Clay-mineral data (\%), Site 548 (Hole 548A).

\begin{tabular}{lcccc}
\hline $\begin{array}{c}\text { Sample } \\
\text { (interval in cm) }\end{array}$ & $\begin{array}{c}\text { Montmoril- } \\
\text { lonite }\end{array}$ & $\begin{array}{c}\text { Mixed } \\
\text { layers }\end{array}$ & Illite & $\begin{array}{c}\text { Kaolinite } \\
+ \\
\text { chlorite }\end{array}$ \\
\hline $11-3,107-109$ & 36 & 15 & 42 & 7 \\
$11-3,123-125$ & 46 & 3 & 44 & 7 \\
$11-3,139-141$ & 41 & 5 & 34 & 19 \\
$16-3,57-59$ & 64 & 17 & 17 & 2 \\
$16-3,75-77$ & 61 & 22 & 15 & 2 \\
$22-6,13-15$ & 71 & 10 & 17 & 2 \\
$22-6,20-23$ & 60 & 13 & 24 & 2 \\
$22-6,24-27$ & 66 & 13 & 20 & 1 \\
$28-6,21-24$ & 32 & 5 & 54 & 9 \\
$28-6,37-40$ & 80 & 0 & 15 & 5 \\
\hline
\end{tabular}

cant depositional and environmental change was associated with formation of the contact (Fig. 6). Before the hiatus occurred, nannofossil chalk accumulated slowly $(1 \mathrm{~cm} / 1600$ yrs.) on a well-oxygenated (low TOC; burrowing infauna; sparse Bolivina [see Poag and Low, this vol.]), relatively cool, epibathyal substrate that contained a rich microfauna and an abundant invertebrate infauna. High generic foraminiferal diversity (24-28) suggests that the benthic environment was relatively stable. However, a drop in the percentage of benthic foraminifers and in the number of benthic genera, and an increase in Globigerina and Bolivina just below the contact, may be indicators that an environmental shift was beginning to have some effect on both the near-surface 

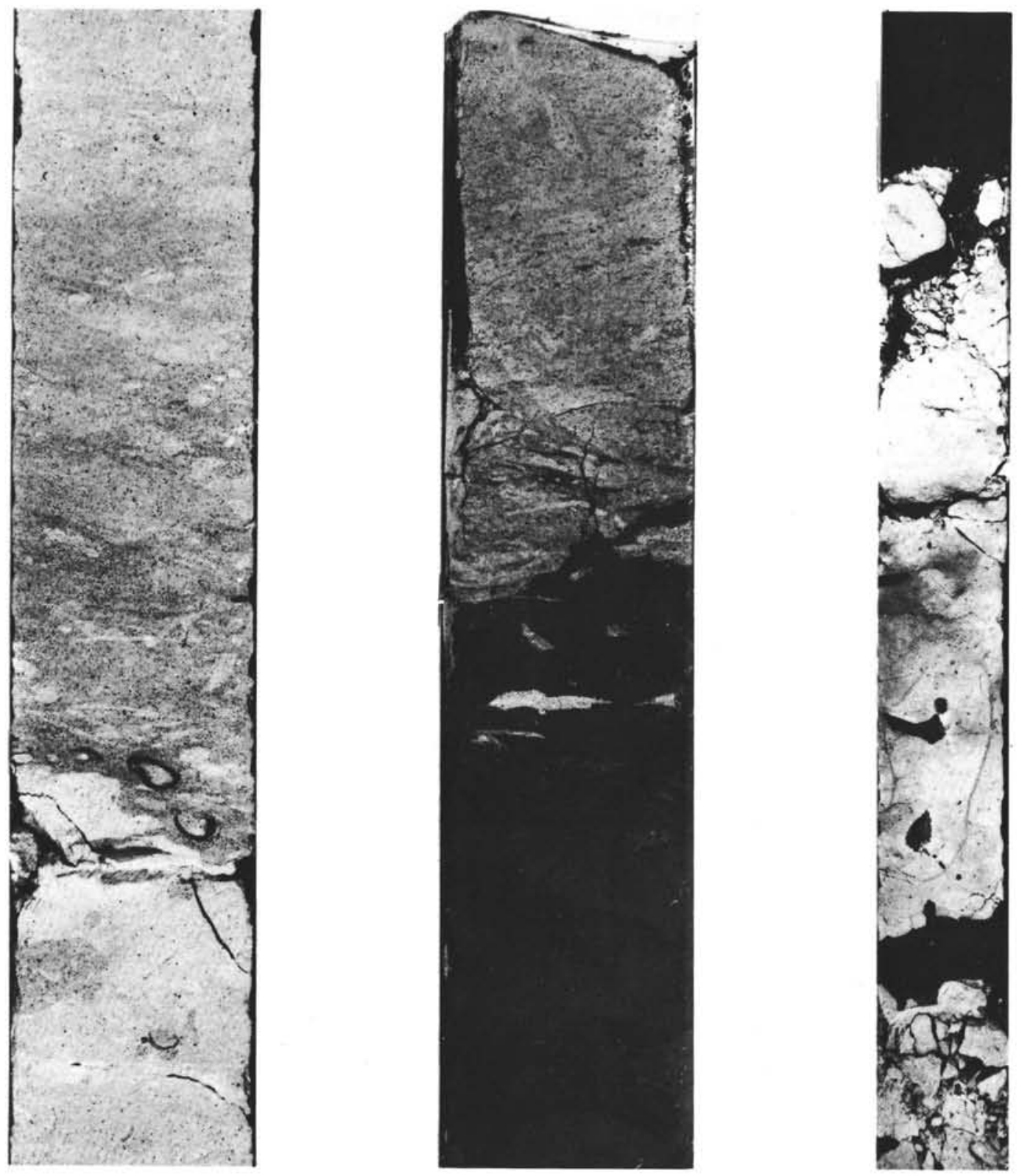


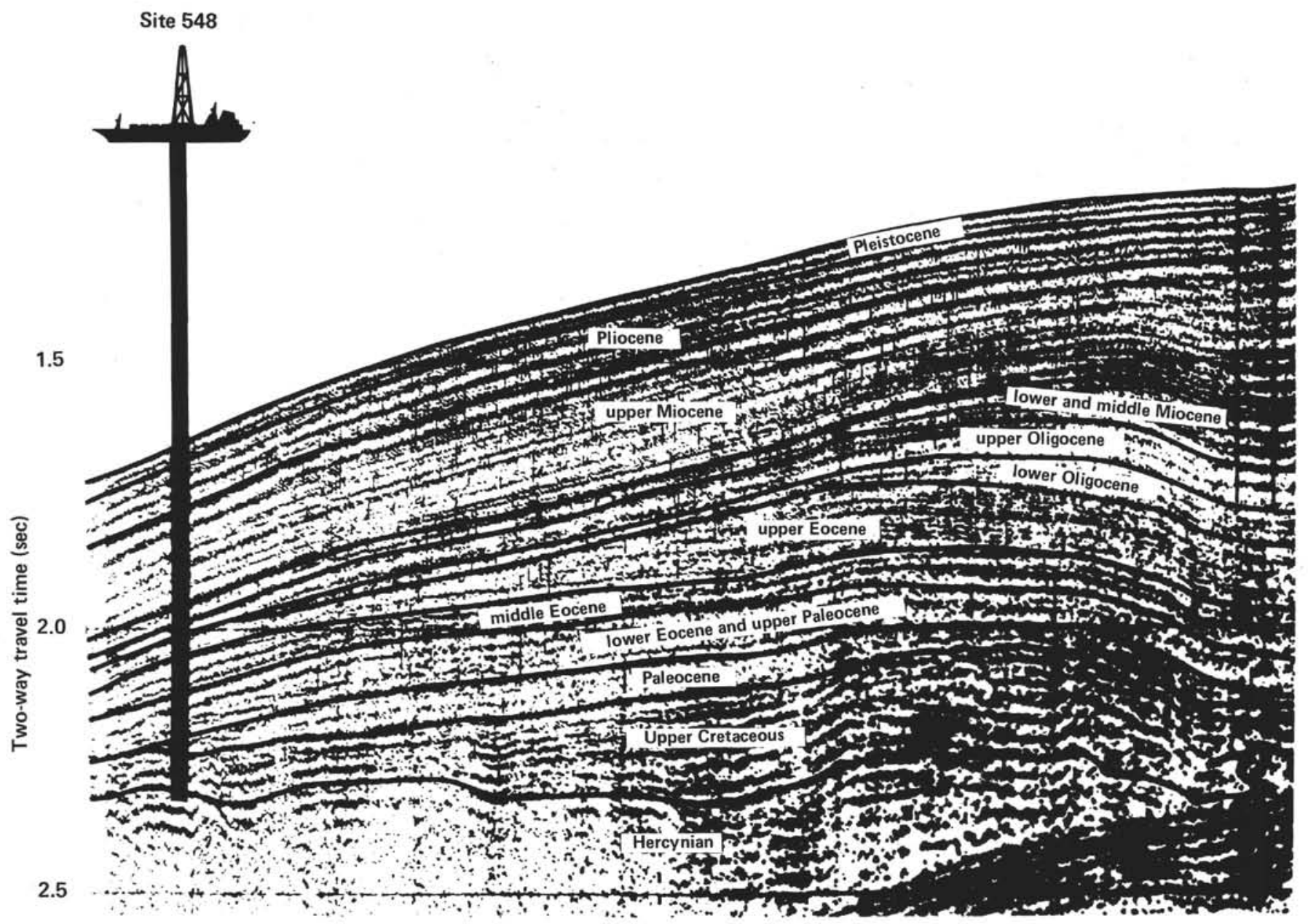

Figure 3. Single-channel, high-resolution seismic profile across Site 548.

water mass and the benthic environment prior to the hiatus. This shift may have been caused by a cooling climate related to the expansion of Antarctic ice that took place during the hiatus (Woodruff et al., 1981; Fig. 7).

During the 6-m.y. hiatus represented by the unconformity, eustatic sea level dropped considerably. Vail and Hardenbol (1979) show that this took place in at least two marked steps (Fig. 7), and that erosion was widespread on continental shelves. In the deep Atlantic Basin, extensive erosion also has been noted during this interval (Fig. 7). We cannot determine how many erosive and nondepositional episodes may have taken place at Site 548 during the hiatus, but deposition resumed when a turbidity current crossed the site, eroding the chalky substrate and rapidly depositing a finely laminated mudstone which encloses displaced foraminifers. The epibathyal nature of the displaced assemblages indicates that displacement was probably from a relatively nearby upper-slope biotope. Even though sea level was much lower, no indications of displaced shelf assemblages have been recognized. The lower number of genera suggests either that some sorting of the benthic assemblage has taken place during transport or that the environment from which the assemblage was displaced was less stable than Site 548 was before the hiatus. The significant increase in Bolivina suggests that the water mass contained less oxygen after the hiatus (see Poag and Low, this vol.). The major change in the planktonic assemblage suggests that the near-surface water mass was quite different after the hiatus. The predominance of Globigerina and the composition of the nannofossil assemblage (Müller, this vol.) suggest cooler surface waters, a condition also suggested for bottom waters by the slightly greater $\delta^{18} \mathrm{O}$ values. Although most workers interpret this isotopic change as having resulted from increased ice volume (Savin et al., 1975; Shackleton and Kennett, 1975; Woodruff et al., 1981), Matthews and Poore (1980) argue for bottom-water cooling in the middle Miocene.

\section{UPPER OLIGOCENE UNCONFORMITY}

\section{Location, Age, Hiatus}

This unconformity forms a diagonal contact between 70 and $72 \mathrm{~cm}$ in Section 548A-16-3 (Fig. 2). At the contact, nannofossil Zone NP24 (upper Oligocene) overlies NP23 (lower Oligocene). The extreme thinness of Zone NP23 indicates that a hiatus of approximately $4 \mathrm{~m} . \mathrm{y}$. is represented by the unconformity.

On both high-resolution and multichannel seismic reflection profiles, this unconformity is the most obvious truncating event, as it terminates a thick wedge of lower 


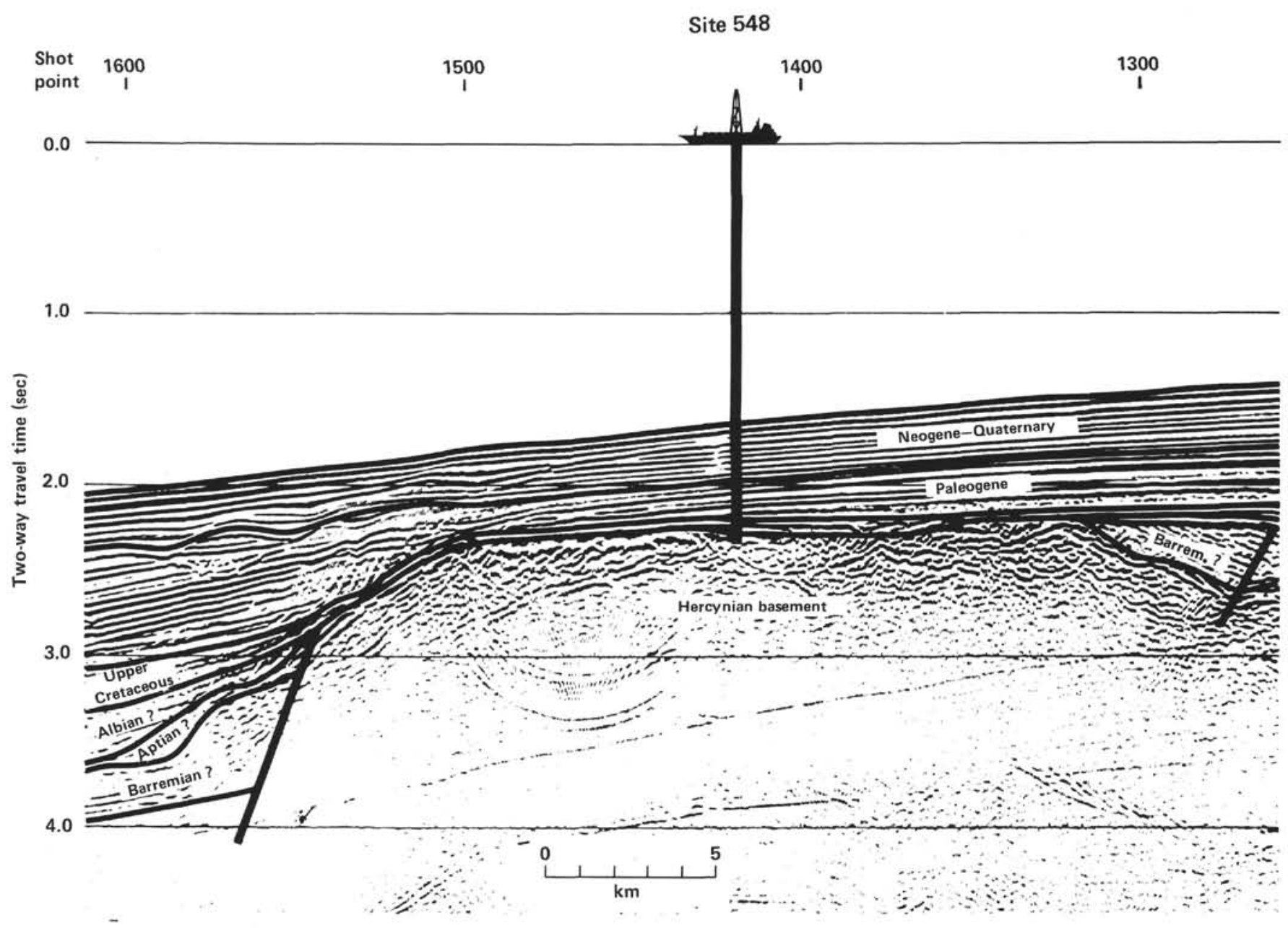

Figure 4. Multichannel seismic profile OC 202 across Site 548.

Oligocene sediments updip and downdip from Site 548, having reduced the Oligocene section at the site to its thinnest part (Figs. 3 and 4). Of special interest is a deep erosional channel that was created beneath shot-point 1550 of Figure 4, eroding into the top of the Eocene.

\section{Lithology}

\section{Visual Description}

Sediment above the contact is hard, light greenish gray (5GY $8 / 1$ and 5G 8/1), burrow-mottled, foraminiferal nannofossil chalk. Several thick-shelled mollusk fragments are present at the base of the unit in an indistinctly and coarsely laminated interval between 56 and $72 \mathrm{~cm}$ in Section 548A-16-3 (Fig. 2). Above 548A-16-3, $56 \mathrm{~cm}$, the sediment is homogeneous. Below the contact, the sediment is hard, homogeneous, bluish white (5B 9/1), burrow-mottled nannofossil chalk.

The contact is an irregular diagonal line between the sharply contrasting major lithofacies. Darker upper sediment fills burrows in the lighter chalk, and numerous inclusions of lighter chalk are reworked into the darker layers as much as $15 \mathrm{~cm}$ above the contact. Examination of nannofossil assemblages from these reworked inclu- sions confirms that they are indeed composed of the NP23 chalk.

\section{Grain Size and Clay Mineralogy}

Median grain size increases appreciably above the contact (Table 1), but additional sampling is needed to confirm the trend. No significant change takes place among clay minerals (Table 2). Lack of any appreciable change on the gamma-ray log at this contact also indicates that clay content does not change.

\section{Isotopic Analysis}

Oxygen isotopic results do not change significantly across the unconformity, but carbon isotopic results are persistently lighter above the contact (Table 3; Fig. 5).

\section{Foraminiferal Analyses}

Several distinct foraminiferal changes are associated with the upper Oligocene unconformity at 548A-16-3, $70 \mathrm{~cm}$. In the benthic assemblage, Cibicides is consistently the most abundant form below the contact (Table 6). It remains so just above the contact, but Bolivina and Epistominella share its predominance in the upper two samples. These are typical epibathyal associations, 
Table 3. Stable isotopic results (\% PDB), Site 548 (Hole 548A).

\begin{tabular}{lrrll}
\hline $\begin{array}{c}\text { Core-Section, } \\
\text { sample level }(\mathrm{cm})\end{array}$ & ${ }^{18} \mathrm{O}$ & ${ }^{13} \mathrm{C}$ & Chronostratigraphy & Zonation \\
\hline $11-3,97$ & 2.00 & 1.42 & & \\
$11-3,101$ & 2.03 & 1.39 & & \\
$11-3,115$ & 1.68 & 1.47 & upper Miocene & NN11 \\
$11-3,126$ & 1.71 & 0.94 & middle Miocene & NN6 \\
$11-3,136$ & 1.80 & 0.82 & & \\
$16-3,52$ & 1.09 & 0.61 & & \\
$16-3,59$ & 1.10 & 0.70 & & \\
$16-3,65$ & 0.89 & 0.76 & upper Oligocene & NP24 \\
$16-3,73$ & 1.02 & 0.84 & lower Oligocene & NP23 \\
$16-3,81$ & 1.04 & 1.07 & & \\
$16-3,86$ & 0.90 & 0.96 & & \\
$16-3,93$ & 0.90 & 1.00 & & \\
& & & & \\
$22-5,135$ & -0.69 & 0.79 & & \\
$22-5,141$ & -0.83 & 0.46 & & \\
$22-6,0$ & -0.72 & 0.21 & & \\
$22-6,3$ & -0.71 & 0.72 & & \\
$22-6,8$ & -0.92 & 0.30 & middle Eocene & NP14 \\
$22-6,18$ & -1.54 & -0.11 & lower Eocene & NP12 \\
$22-6,29$ & -1.46 & -0.30 & & \\
$22-6,43^{\mathrm{a}}$ & -1.02 & 0.59 & & $\mathrm{NP9}$ \\
$28-6,7$ & -0.52 & 1.05 & & \\
$28-6,16$ & -0.58 & 1.13 & & \\
$28-6,25$ & -0.78 & 1.01 & upper Paleocene & \\
$28-6,42$ & -0.07 & 1.29 & lower Paleocene & NP3 \\
$28-6,55$ & -0.27 & 1.04 & & \\
$28-6,73^{\mathrm{a}}$ & 0.08 & 1.35 & & \\
\hline
\end{tabular}

Note: Unconformities shown by horizontal rules.

avery small samples; results less reliable.

similar to those near the middle Miocene/upper Miocene unconformity, but here Cassidulina and Eponides are less prominent. Generic diversity changes very little, but is persistently lower above the contact. Percentage of benthic species increases significantly across the boundary, but returns to a pre-hiatus value in the highest sample.

Among individual genera, Epistominella and Bolivi$n a$ display the most marked changes in abundance, although they are rather subtle. Both genera have lowest values adjacent to the boundary, and return to approximately pre-hiatus values in the upper two samples. Changes in planktonic genera are few, but Globigerinita begins to replace Globigerina two samples below the contact, and continues to increase steadily as Globigeri$n a$ declines (Table 5).

\section{Interpretation}

The nature of the data cited here (Fig. 6) suggests that before the hiatus, pelagic chalk was accumulating slowly $(1 \mathrm{~cm} / 5300$ yrs.) in a well-oxygenated (low TOC; burrowing infauna; few Bolivina), relatively cool, epibathyal environment. Relatively high benthic generic diversity (28-30) suggests a stable environment. Shifts in abundances of Globigerinita, Globigerina, Epistominel$l a$, and Bolivina, in percentage of benthic foraminifers, and in $\delta^{13} \mathrm{C}$ values just below the boundary may indicate that the environment began to change just before the hi-
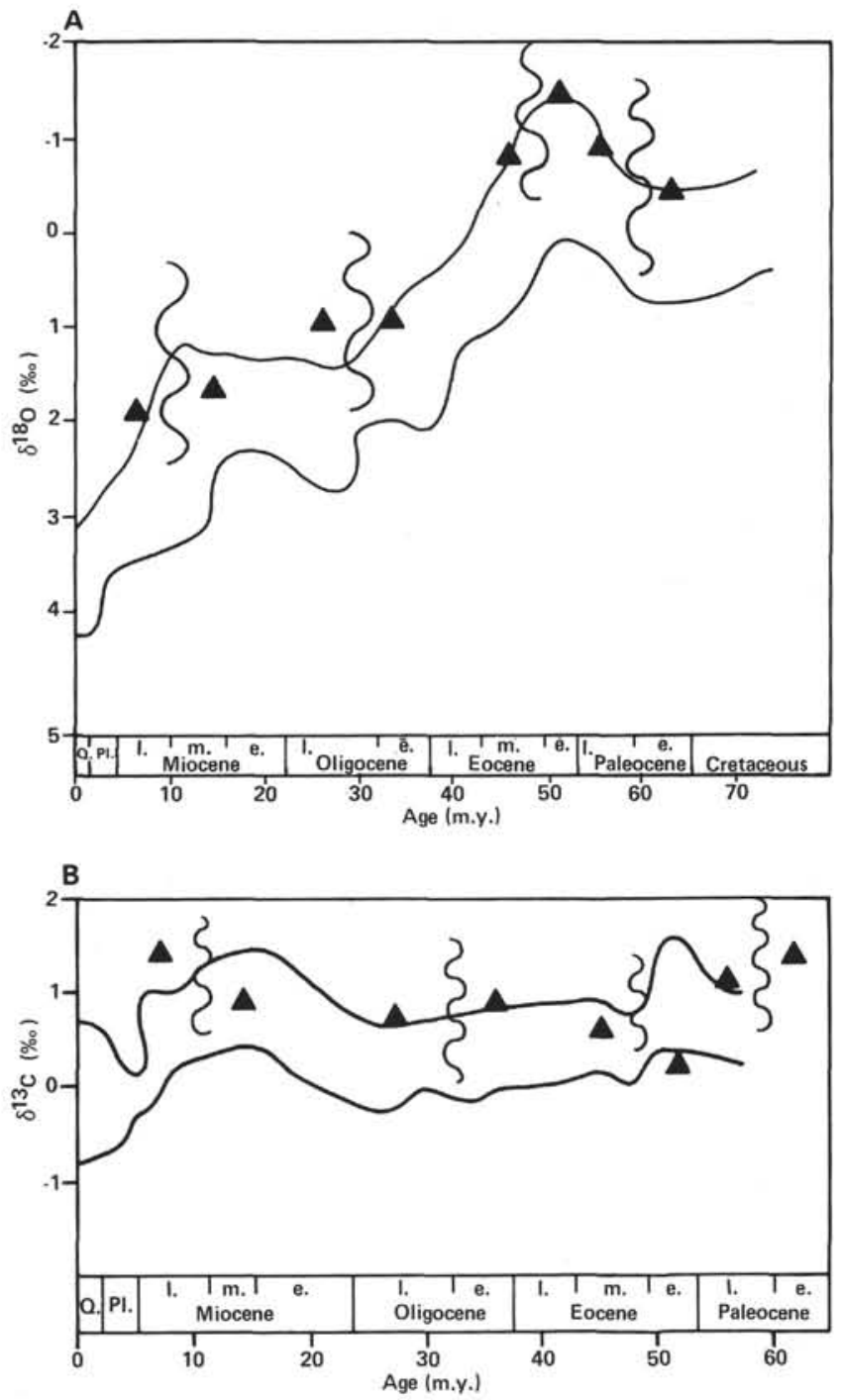

Figure 5. A. Trends in $\delta^{18} \mathrm{O}$ at Site $548(\mathbf{\Delta})$, compared with data of Savin (1977). B. Trends in $\delta^{13} \mathrm{C}$ at Site 548 ( $\Delta$ ), compared with data of Savin et al. (1975) and Shackleton and Kennett (1975).

atus. The hiatus corresponds to a major sea-level fall (Vail and Hardenbol, 1979; Fig. 7) that caused widespread erosion on continental margins. At about the same time, erosion intensified in abyssal locations in the North Atlantic (Thiede et al., 1981). Phytoplankton and zooplankton from high latitudes moved equatorward during this period (Haq, 1981), suggesting cooling of surface waters. A middle late Oligocene $\delta^{18} \mathrm{O}$ signal in benthic foraminifers, large enough to require continental ice, has been detected only in material from equatorial Pacific DSDP Hole 77B (Keigwin and Keller, 1984). Previous studies lacked sufficient samples to resolve this event, although one-point peaks have been reported (e.g., Savin et al., 1975, Site 167). These new isotopic data support the hypothesis that a sea-level fall about $29 \mathrm{~m}$.y. ago could have resulted from an increase in continental ice buildup.

Following the 4-m.y. hiatus, sea level was much lower (Vail and Hardenbol, 1979) than before the hiatus. The 
Table 4. Census of benthic foraminiferal genera ( $\%$ of total benthic assemblage $>74 \mu \mathrm{m}$ ), Section 548A-11-3.

\begin{tabular}{|c|c|c|c|c|c|c|}
\hline \multirow[b]{2}{*}{ Genus } & \multicolumn{6}{|c|}{ Sample (interval in $\mathrm{cm}$ ) } \\
\hline & $136-138$ & $126-128$ & $115-117$ & $111-115$ & $101-105$ & $97-101$ \\
\hline Bolivina & 2.7 & 7.4 & 19.1 & 17.8 & 16.7 & 14.6 \\
\hline Cassidulina & 13.6 & 17.8 & 14.1 & 22.5 & 16.7 & 14.2 \\
\hline Cibicides & 5.3 & 2.1 & 6.1 & 5.4 & 8.6 & 7.1 \\
\hline Epistominella & 23.4 & 32.3 & 13.3 & 10.9 & 8.6 & 5.4 \\
\hline Eponides & 2.9 & 11.0 & 9.3 & 14.1 & 9.0 & 16.0 \\
\hline Gyroidina & 5.3 & 6.0 & 5.9 & 5.8 & 8.6 & 7.5 \\
\hline Melonis & 4.0 & 1.8 & 8.2 & 3.3 & 9.9 & 8.8 \\
\hline Stilostomella & 6.4 & 2.1 & 2.4 & - & 3.1 & 4.8 \\
\hline Uvigerina & 4.8 & 3.5 & 2.9 & 6.9 & 6.2 & 7.8 \\
\hline Alabamina & 0.3 & - & 0.3 & - & - & - \\
\hline Anomalina & 1.1 & - & - & - & - & - \\
\hline Astrononion & 0.3 & 0.4 & - & 0.7 & - & - \\
\hline Bulimina & 2.1 & 3.2 & 2.4 & 0.4 & 0.3 & 1.0 \\
\hline Dentalina & 1.3 & - & 1.3 & - & 0.9 & 1.4 \\
\hline Eggerella & 1.1 & 0.4 & 0.5 & - & 0.3 & - \\
\hline Ehrenbergina & - & - & 2.4 & 2.2 & 0.3 & 0.3 \\
\hline Fissurina & 4.0 & 0.7 & 1.3 & 0.7 & 0.9 & 0.3 \\
\hline Fursenkoina & 0.5 & - & 0.8 & - & - & - \\
\hline Karreriella & 0.5 & - & - & 0.4 & - & - \\
\hline Lagena & 1.3 & 2.1 & 1.3 & - & 0.6 & 0.7 \\
\hline Lenticulina & 1.9 & 0.7 & 1.1 & 0.4 & - & 0.3 \\
\hline Martinottiella & - & 0.4 & - & - & 0.3 & - \\
\hline Neoconorbina & 0.3 & - & - & - & - & - \\
\hline Nodosaria & - & 0.4 & 0.3 & 0.7 & 0.3 & 0.7 \\
\hline Nonion & - & 0.4 & - & 1.8 & 0.6 & 1.0 \\
\hline Oolina & 0.3 & 0.4 & - & - & - & 1.7 \\
\hline Oridorsalis & 2.1 & - & 3.2 & 1.1 & 1.2 & 0.3 \\
\hline Orthomorphina & 1.9 & 2.1 & - & 1.1 & 0.6 & - \\
\hline Osangularia & 0.5 & 0.7 & 0.8 & - & - & - \\
\hline Pleurostomella & 1.9 & 0.7 & - & 0.7 & 1.2 & 1.0 \\
\hline Pullenia & 1.6 & 1.4 & 2.1 & 0.4 & 2.8 & 1.4 \\
\hline Quinqueloculina & 1.3 & - & - & - & - & - \\
\hline Rectuvigerina & 0.5 & - & - & - & - & - \\
\hline Rosalina & 0.3 & 0.7 & - & 2.2 & - & - \\
\hline Rotorbinella & 0.8 & - & 0.8 & 2.2 & 0.9 & - \\
\hline Sigmoilopsis & 1.3 & 0.4 & 0.3 & 0.4 & 0.3 & - \\
\hline Sphaeroidina & 0.8 & - & - & - & - & - \\
\hline Spirobolivina & 0.8 & 0.4 & - & - & 0.3 & 0.3 \\
\hline Spiroloculina & 0.3 & - & - & - & - & - \\
\hline Textularia & 0.3 & - & - & - & - & 0.3 \\
\hline Trifarina & 0.8 & 0.4 & - & - & - & 0.3 \\
\hline "Tubuloaperta" & 0.3 & - & - & - & - & - \\
\hline Turrilina & - & - & - & 0.7 & 0.6 & 2.4 \\
\hline Total specimens & 376 & 282 & 376 & 276 & 324 & 294 \\
\hline$\%$ benthic & 4.3 & 2.3 & 2.7 & 5.3 & 3.7 & 2.7 \\
\hline No. of genera & 42 & 30 & 26 & 25 & 27 & 27 \\
\hline
\end{tabular}

post-erosion sediment appears to be part of a turbidite whose associated density current eroded the underlying chalk before rapidly depositing coarser particles. The foraminiferal fauna is thus a displaced one, but faunal composition (Table 6) and pelagic nature of the sediments indicate that the turbidity current originated nearby on the upper slope. The decline in Globigerina indicates that the upper water column was slightly warmer following the hiatus. This interpretation is supported by the presence of a warmer-water nannofossil assemblage (Müller, this vol.). The insignificant changes in benthic faunal and isotopic data suggest, however, that little if any environmental change took place at the seafloor.

\section{LOWER EOCENE/MIDDLE EOCENE UNCONFORMITY}

\section{Location, Age, Hiatus}

This unconformity is present at approximately 15 to $16 \mathrm{~cm}$ in Section 548A-22-5 (Fig. 2). At the contact,
Table 5. Census of planktonic foraminiferal genera ( $\%$ of total planktonic assemblage $>125 \mu \mathrm{m}$ ), Site 548 (Hole 548A).

\begin{tabular}{|c|c|c|c|c|c|c|c|}
\hline & \multicolumn{6}{|c|}{$\begin{array}{l}\text { Core 11, Section 3; } \\
\text { interval (in } \mathrm{cm} \text { ) }\end{array}$} & \\
\hline & $136-139$ & $126-128$ & $115-118$ & $111-115$ & $101-105$ & $97-101$ & \\
\hline Globigerina & 24 & 37 & 63 & 47 & 60 & 63 & \\
\hline Globigerinoides & 03 & - & 02 & P & $\mathrm{P}$ & - & \\
\hline Globorotalia & 04 & 04 & 05 & 04 & 04 & 06 & \\
\hline Neogloboquadrina & 08 & 07 & 20 & 41 & 26 & 24 & \\
\hline Turborotalia & 46 & 41 & 02 & - & 01 & 01 & \\
\hline Other genera & 07 & 05 & 04 & 03 & 02 & 01 & \\
\hline \multirow[t]{3}{*}{ Indeterminate } & 07 & 06 & 03 & 05 & 07 & 05 & \\
\hline & \multicolumn{7}{|c|}{$\begin{array}{l}\text { Core 16, Section 3; } \\
\text { interval (in } \mathrm{cm} \text { ) }\end{array}$} \\
\hline & 93-95 & $86-89$ & $81-84$ & $73-76$ & $65-68$ & $5 y-62$ & $52-56$ \\
\hline Globigerina & 67 & 58 & 68 & 57 & 39 & 46 & 33 \\
\hline Globigerinita & 24 & 27 & 25 & 36 & 40 & 40 & so \\
\hline Other genera & 01 & 01 & $\mathrm{P}$ & 01 & 03 & 01 & 03 \\
\hline \multirow[t]{3}{*}{ Indeterminate } & 08 & 14 & 07 & 06 & 19 & 13 & 13 \\
\hline & \multicolumn{6}{|c|}{$\begin{array}{l}\text { Core 22, Sections 5, 6: } \\
\text { interval (in } \mathrm{cm} \text { ) }\end{array}$} & \\
\hline & $43-46$ & $29-32$ & $18-20$ & $8-12$ & $3-7$ & $0-3$ & \\
\hline Acarinina & 61 & 72 & 46 & 21 & 23 & 17 & \\
\hline Morozovella & 04 & 10 & 20 & 19 & 15 & 18 & \\
\hline Subbotina & 26 & 15 & 22 & so & 46 & 43 & \\
\hline Other genera & 05 & 01 & 02 & P & 13 & 02 & \\
\hline \multirow[t]{3}{*}{ Indeterminate } & 04 & 03 & 09 & 09 & $\theta 3$ & 20 & \\
\hline & \multicolumn{7}{|c|}{$\begin{array}{l}\text { Core 28, Sections 5, 6; } \\
\text { interval (in } \mathrm{cm} \text { ) }\end{array}$} \\
\hline & $73-75$ & $55-57$ & $42-44$ & $25-27$ & $16-17$ & $7-9$ & $105-107$ \\
\hline Acarinina & - & - & 08 & 38 & 36 & 41 & 35 \\
\hline Morozovella & - & - & 01 & 16 & 18 & 15 & 16 \\
\hline Planorotalites & 12 & 09 & 04 & - & - & - & - \\
\hline Subbotina & 75 & 65 & 55 & 41 & 41 & 35 & 40 \\
\hline Turborotalia & 08 & 17 & 26 & - & - & - & - \\
\hline Other genera & - & 03 & - & 01 & 02 & 02 & 03 \\
\hline Indeterminate & 05 & 05 & 06 & 03 & 03 & 07 & 06 \\
\hline
\end{tabular}

nannofossil Zone NP14 (middle Eocene) rests above NP12 (lower Eocene), indicating a hiatus of $\sim 2$ m.y.

On the high-resolution seismic reflection profile, this unconformity truncates lower Eocene strata updip from the site (Fig. 3). The unconformity is downlapped by overlying middle Eocene strata in the same vicinity. On the multichannel line (Fig. 4), the unconformity truncates a wedge of lower Eocene strata seaward from Site 548 between shot-points 1500 and 1550 , and appears to erode down to Cretaceous beds near the edge of the basement block ( $\sim$ shot-point 1490).

\section{Lithology}

\section{Visual Description}

Sediment above the contact is greenish gray (5GY 7/ 1), firm, moderately burrowed, silty and sandy, indistinctly laminated to homogeneous nannofossil chalk (Fig. 2). Below the contact, sediment is dark gray-brown (2.5Y 4/2), firm, moderately burrowed, very marly, homogeneous nannofossil chalk. The contact is an irregular diagonal sharp line between the contrasting lithologies. Lighter sediment from above the contact has been incorporated in burrow fillings as deep as $5 \mathrm{~cm}$ below the contact. Dark lower sediment is reworked as high as $10 \mathrm{~cm}$ above the contact. Subhorizontal laminations can be observed in the first $4 \mathrm{~cm}$ above the contact, but above this the strata are more homogeneous.

\section{Grain Size and Clay Mineralogy}

Mean grain size increases significantly upsection across the unconformity, from 7.6 to $6.8 \phi$ (Table 1). No large 

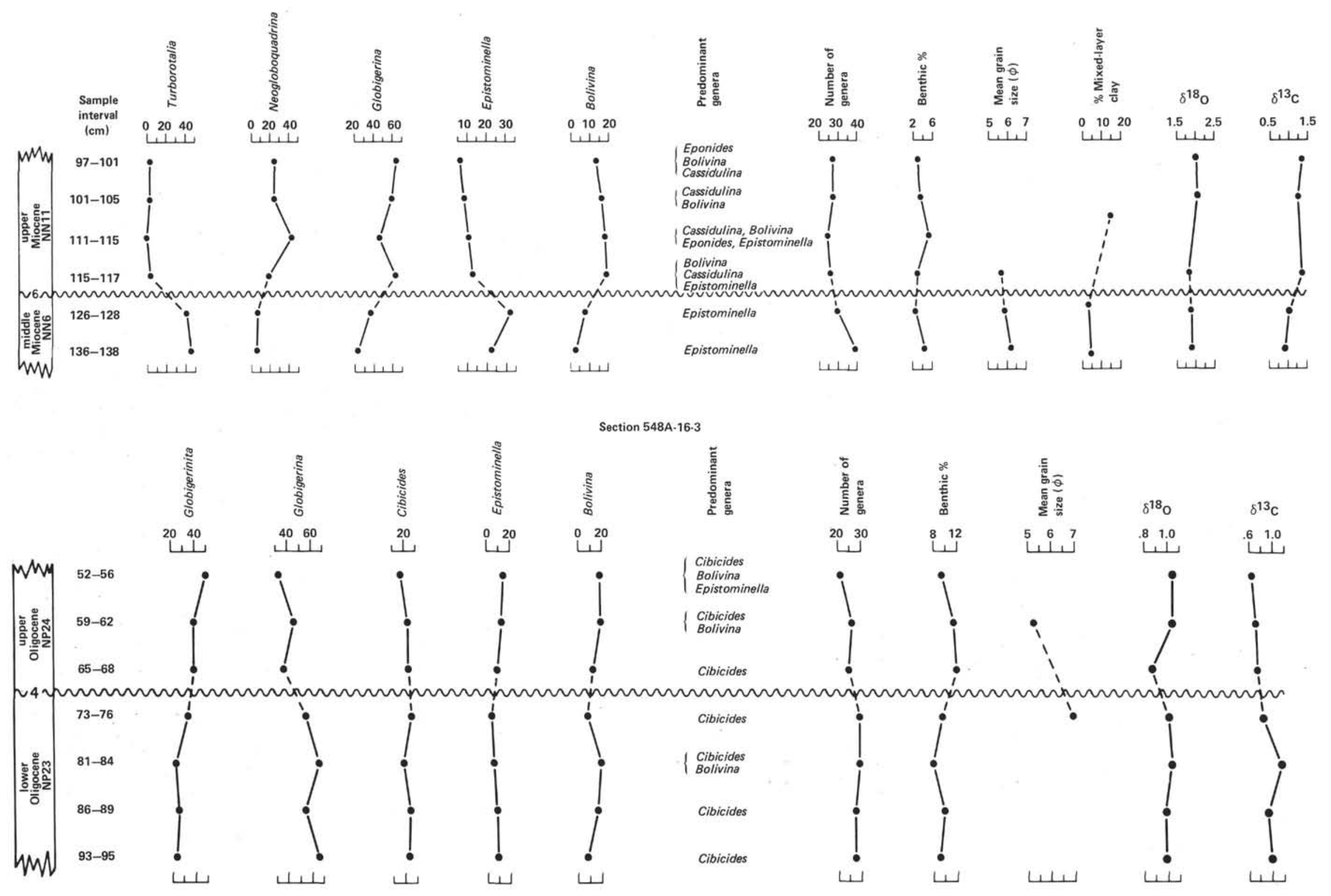

Figure 6. Data summary for Sections 548A-11-3 and 548A-16-3. Left-hand column shows stratigraphic position and nannofossil zones. Second column shows sample interval (cm from top of section). Benthic foraminiferal genera plotted as percentage of total benthic assemblage: likewise for planktonic genera. Wiggly horizontal line denotes position of unconformity. Number that breaks wiggly line in left-hand column represents duration of hiatus. 


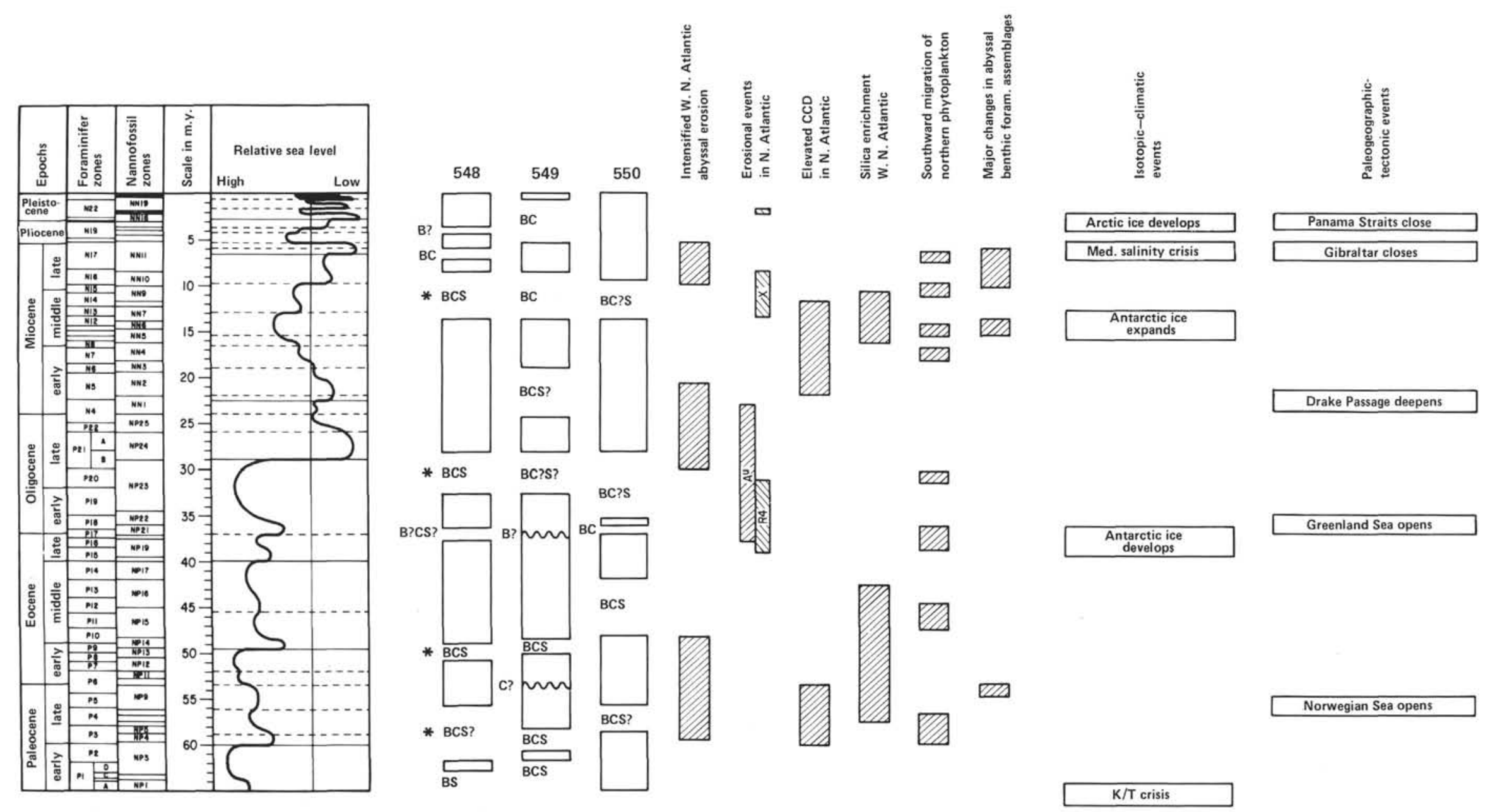

Figure 7. Comparison of stratigraphic gaps at DSDP-IPOD Sites 548, 549, and 550 with sea-level fluctuations and isotopic, climatic, and geographic events. ${ }^{*}=$ major unconformity (Vail et al., 1980); B = biostratigraphic gap; C = lithic discontinuity; $\mathrm{S}=$ seismic discontinuity; $\mathrm{A}^{\mathrm{u}}=$ erosional unconformity widespread in western North Atlantic (Tucholke, 1979 ); $\mathrm{R} 4$ = erosional unconformity widespread in eastern North Atlantic (Miller and Tucholke, 1983); X = erosional unconformity widespread in western North Atlantic (Tucholke and Laine, 1984). 
Table 6. Census of benthic foraminiferal genera ( $\%$ of total benthic assemblage $>74 \mu \mathrm{m}$ ), Section 548A-16-3.

\begin{tabular}{|c|c|c|c|c|c|c|c|}
\hline \multirow[b]{2}{*}{ Genus } & \multicolumn{7}{|c|}{ Sample (interval in $\mathrm{cm}$ ) } \\
\hline & $93-95$ & 86-89 & $81-84$ & $73-76$ & $65-68$ & $59-62$ & $52-56$ \\
\hline Bolivina & 8.5 & 15.0 & 18.1 & 7.0 & 10.6 & 18.1 & 16.8 \\
\hline Bulimina & 7.3 & 8.7 & 3.9 & 4.4 & 6.8 & 4.4 & 3.9 \\
\hline Cassidulina & 14.9 & 10.8 & 12.5 & 14.9 & 14.7 & 12.2 & 11.2 \\
\hline Cibicides & 22.6 & 22.3 & 20.1 & 26.3 & 24.3 & 21.3 & 19.3 \\
\hline Epistominella & 9.7 & 9.8 & 7.1 & 6.1 & 9.9 & 12.2 & 15.1 \\
\hline Eponides & 2.4 & 3.5 & 2.9 & 3.1 & 5.5 & 2.8 & 2.8 \\
\hline Nuttallides & 6.0 & 4.9 & 4.5 & 7.5 & 5.1 & 8.8 & 5.3 \\
\hline Alabamina & 0.4 & 0.3 & - & 0.9 & - & - & - \\
\hline Amphicoryna & 0.8 & - & - & - & - & - & - \\
\hline Asterigerina & 0.4 & - & - & - & - & - & - \\
\hline Biapertorbis & - & 0.3 & 2.6 & 0.4 & 0.7 & 0.6 & 0.7 \\
\hline Buliminella & 2.8 & 1.0 & 4.5 & 1.3 & - & 1.3 & 1.1 \\
\hline Buliminita & 0.4 & - & - & 0.4 & - & - & - \\
\hline Dentalina & 2.8 & 1.7 & 0.3 & - & - & 0.3 & 3.2 \\
\hline Dorothia & - & - & 0.3 & - & 0.3 & - & - \\
\hline Elphidium & 0.4 & - & - & - & - & - & - \\
\hline Fissurina & - & - & - & 0.4 & - & - & - \\
\hline Florilus & 0.8 & 1.0 & 1.9 & 0.9 & - & 0.3 & - \\
\hline Gyroidina & 4.8 & 2.8 & 2.6 & 0.4 & 5.1 & 1.9 & 1.1 \\
\hline Guttulina & - & 0.3 & 0.3 & - & - & - & - \\
\hline Heronallenia & - & - & - & 0.4 & 0.7 & - & 1.1 \\
\hline Lagena & 0.8 & 0.3 & 0.6 & - & 0.3 & - & 0.7 \\
\hline Lenticulina & 1.2 & 1.0 & 1.3 & 1.3 & 0.7 & 0.6 & - \\
\hline Melonis & 1.2 & 1.7 & - & 1.8 & - & 2.8 & - \\
\hline Neoconorbina & - & - & 0.3 & - & - & - & - \\
\hline Nodosaria & - & - & - & 0.4 & - & - & - \\
\hline Oolina & - & - & 1.3 & - & - & 0.3 & - \\
\hline Oridorsalis & - & 0.7 & 0.3 & - & 0.3 & 0.6 & 0.4 \\
\hline Osangularia & - & 0.7 & - & 1.3 & - & - & - \\
\hline Pararotalia & - & - & - & 0.9 & 0.3 & - & - \\
\hline Planulina & - & 0.7 & - & - & 0.3 & 0.3 & - \\
\hline Pleurostomella & - & 0.7 & 0.6 & - & 0.7 & - & - \\
\hline Pullenia & 0.4 & 0.7 & 1.9 & 2.6 & 1.4 & 1.6 & 1.8 \\
\hline Rosalina & 3.6 & 1.7 & 3.2 & 4.4 & 1.7 & 2.2 & 2.5 \\
\hline Reussella & - & - & 0.3 & 0.4 & - & - & - \\
\hline Siphonina & - & - & - & - & 0.3 & - & - \\
\hline Spirillina & - & 0.3 & - & - & 0.7 & 0.6 & 0.4 \\
\hline Stilostomella & 3.2 & 2.8 & 2.9 & 3.0 & 4.5 & 4.7 & 3.5 \\
\hline Textularia & - & - & 0.3 & 0.4 & - & 0.6 & 0.4 \\
\hline Trifarina & 1.6 & 1.7 & 1.6 & 1.8 & 2.4 & 3.4 & 5.3 \\
\hline Turrilina & 0.4 & - & - & - & - & - & - \\
\hline Uvigerina & 2.0 & 3.5 & 2.6 & 5.7 & 2.1 & 0.3 & 2.1 \\
\hline Total specimens & 248 & 287 & 309 & 228 & 292 & 320 & 285 \\
\hline$\%$ benthic & 9.3 & 10.0 & 8.0 & 9.6 & 12.0 & 11.6 & 9.6 \\
\hline No. of genera & 27 & 28 & 30 & 30 & 25 & 26 & 22 \\
\hline
\end{tabular}

change takes place among clay minerals (Table 2), but the two samples below the contact have closer affinities to each other than to the sample above the contact (percentage of mixed-layer clays and percentage of illite are higher). Gamma-ray intensity is 40 API units higher below the contact, which is a clear indication of higher clay content.

\section{Isotopic Changes}

The $\delta^{18} \mathrm{O}$ and $\delta^{13} \mathrm{C}$ values change in unison throughout the sampled interval (Table 3; Fig. 5). Both become markedly lighter in the two samples just below the contact, then become heavier again above the contact and remain so.

\section{Foraminiferal Analyses}

Rich benthic foraminiferal assemblages in these samples display marked changes across the contact, as a total assemblage and as individual genera (Table 7). Bulimina is consistently the most abundant genus above and below the contact, but whereas it shares its abundance
Table 7. Census of benthic foraminiferal genera ( $\%$ of total benthic assemblage $>74 \mu \mathrm{m}$ ), Sections 548A-22-5 and 548A-22-6.

\begin{tabular}{|c|c|c|c|c|c|c|c|c|c|}
\hline \multirow[b]{2}{*}{ Genus } & \multicolumn{9}{|c|}{ Sample (interval in $\mathrm{cm}$ ) } \\
\hline & $43-45$ & 29-32 & $18-20$ & $8-12$ & 3-7 & $0-3$ & $141-143$ & $135-137$ & $103-10$ \\
\hline Bolivina & 11.0 & 5.3 & 8.7 & 1.0 & 2.3 & 15.7 & 18.2 & 23.7 & 21.9 \\
\hline Bulimina & 11.8 & 17.8 & 15.2 & 20.6 & 23.3 & 12.9 & 11.5 & 12.0 & 11.8 \\
\hline Cassidulina & 7.5 & 8.3 & 13.9 & 9.1 & 7.3 & 6.6 & 4.5 & 3.7 & 3.2 \\
\hline Cibicides & 3.1 & 15.9 & 7.4 & 7.1 & 8.3 & 6.0 & 2.8 & 0.8 & 2.2 \\
\hline Epistominella & 7.5 & 3.4 & 6.5 & 0.7 & 1.7 & 7.8 & 10.1 & 12.0 & 10.0 \\
\hline Eponides & 10.3 & 6.4 & 10.0 & 0.7 & - & 5.6 & 7.0 & 3.7 & 0.7 \\
\hline Gyroidina & 5.9 & 0.8 & 5.6 & 2.4 & 3.3 & 4.7 & 3.5 & 4.1 & 4.7 \\
\hline Nuttallides & 1.6 & 5.3 & 3.0 & 7.8 & 3.3 & 3.4 & - & 0.8 & 0.7 \\
\hline Osangularia & 2.4 & 7.6 & 3.9 & 10.1 & 9.0 & 13.5 & 16.1 & 13.7 & 21.5 \\
\hline Stilostomella & 12.5 & 8.3 & 6.0 & 8.1 & 9.3 & 6.3 & 4.2 & 3.3 & 7.9 \\
\hline Alabamina & 0.4 & - & - & - & - & - & - & - & 0.7 \\
\hline Anomalinoides & 2.0 & 2.7 & 3.0 & 4.1 & 4.7 & 1.6 & 2.4 & 2.0 & 1.8 \\
\hline Aragonia & - & - & - & 0.7 & 1.0 & - & 0.3 & 1.2 & 0.4 \\
\hline Astacolus & - & - & 0.9 & 0.3 & 0.3 & - & - & - & - \\
\hline Bolivinopsis & - & - & - & - & 0.3 & 0.6 & - & 0.4 & - \\
\hline Buliminella & - & - & - & 0.7 & 0.7 & 0.6 & 1.7 & 0.4 & 0.4 \\
\hline Cibicidina & - & - & - & - & - & - & 0.3 & - & - \\
\hline Dentalina & 1.6 & 1.9 & 0.9 & 3.7 & 2.0 & 1.9 & 2.8 & 4.6 & 2.2 \\
\hline Ehrenbergina & - & - & - & - & 0.3 & - & - & - & - \\
\hline Fissurina & - & - & - & - & - & - & 0.3 & 0.4 & - \\
\hline Fursenkoina & 1.6 & 0.8 & 1.7 & - & 0.7 & 0.6 & - & - & 0.4 \\
\hline Gavelinelia & - & - & - & 1.7 & 0.3 & 0.3 & 0.7 & - & 0.4 \\
\hline Globulina & - & - & - & - & - & - & - & - & 0.4 \\
\hline "Hanzawaia" & - & 0.8 & 0.9 & - & 0.3 & 0.3 & 0.7 & 0.4 & - \\
\hline Heronallenia & - & - & - & 0.3 & - & - & - & - & - \\
\hline Hoeglundina & 0.4 & - & - & - & - & - & - & - & - \\
\hline Karreriella & - & - & 0.4 & - & - & - & 0.3 & - & 0.4 \\
\hline Kolesnikovella & 0.4 & 0.8 & 0.4 & 0.3 & - & - & - & - & - \\
\hline Lagena & - & - & 0.9 & 0.7 & 0.7 & 0.9 & 0.7 & - & \\
\hline Lenticulina & 1.2 & 1.5 & 0.9 & 0.7 & 0.3 & 0.9 & 0.7 & - & 0.7 \\
\hline Marginulina & - & 0.8 & - & - & - & - & 0.7 & - & - \\
\hline Melonis & 2.4 & 1.9 & - & 3.0 & 0.7 & 1.6 & 0.3 & 3.7 & - \\
\hline Nodosaria & - & - & - & - & - & - & - & 0.4 & 0.7 \\
\hline Oolina & - & - & - & 0.3 & - & - & 0. & 0.4 & - \\
\hline Oridorsalis & 0.4 & - & 2.2 & 1.4 & 1.7 & - & 0.7 & - & 0.7 \\
\hline Orthomorphina & - & - & 0.4 & - & - & - & 0.7 & 1.2 & - \\
\hline Pleurastomella & 2.0 & - & 0.9 & 1.0 & 2.3 & 1.3 & 2.4 & 1.2 & 0.4 \\
\hline Polymorphina & - & - & 0.4 & - & - & - & - & - & - \\
\hline vigerina & - & 0.4 & - & - & - & - & - & - & - \\
\hline Pullen & 0.4 & 1.5 & 1.7 & 0.3 & 1.0 & - & 1.4 & - & 2.2 \\
\hline Pulsip & 2.7 & 1.9 & 2. & 3.0 & 4.7 & 1.6 & 1.0 & 1.2 & 0.4 \\
\hline Quinqueloculina & - & - & 0.4 & - & - & - & - & - & - \\
\hline Rosal & 0.8 & - & - & - & - & - & - & - & - \\
\hline Siphon & 1.2 & 3.8 & 0.9 & 1.0 & 0.7 & - & 0.3 & 0.8 & 0.4 \\
\hline fularia & - & - & - & 0.7 & 0.3 & - & - & - & - \\
\hline Svratkina & 0.4 & - & - & - & - & - & - & - & - \\
\hline Trifarina & - & - & 0.4 & 2.7 & 5.0 & 3.1 & 1.4 & 0.8 & 0.7 \\
\hline Tritax & - & 1.1 & - & 3.0 & 1.0 & 0.6 & 0.3 & - & - \\
\hline "Tubuloaperta" & - & - & 0.4 & - & 0.3 & 0.3 & - & 0.8 & 0.7 \\
\hline Turill & 2.7 & - & - & 0. & 0.7 & 0.6 & 0.3 & - & - \\
\hline Uvigerina & 0.4 & - & - & 0.3 & 0.3 & 0.6 & 0.3 & 0.4 & 1.4 \\
\hline Valvulineria & 0.4 & - & - & - & - & - & - & - & - \\
\hline Vulvulina & - & - & - & 1.4 & 0.7 & - & - & - & - \\
\hline Total & 255 & 264 & 231 & 296 & 301 & 319 & 286 & 241 & 279 \\
\hline & 7.0 & 19.3 & 20.0 & 6.0 & 5.0 & 11.0 & 7.3 & 14.0 & 9.0 \\
\hline No. of genera & 29 & 24 & 29 & 34 & 35 & 27 & 33 & 28 & 30 \\
\hline
\end{tabular}

with Cassidulina, Eponides, and Cibicides in the two samples just below the contact, it is clearly predominant alone in the two samples above the contact (21-23\%). It gradually gives way, however, to an assemblage dominated by Bolivina and Osangularia in the highest four samples. The benthic assemblage is distinctly different from the Neogene assemblages described in the foregoing sections, but is nevertheless one that would be expected in epibathyal Paleogene environments (Berggren and Aubert, 1975).

The number of genera increases slightly just below the contact, and continues this trend above the contact. But it declines again in the upper four samples. On the other hand, the percentage of benthic specimens increases dramatically from 7 to $19-20 \%$ below the contact, and drops back to $5-6 \%$ just above the contact. It then begins a gradually increasing trend, fluctuating between 7 and $14 \%$.

Among individual benthic genera, Eponides, Bolivina, Cassidulina, and Epistominella increase just below the contact and decrease above it (Table 7). But whereas Cassidulina continues to decrease, Eponides, Bolivina, 
and Epistominella increase again in the upper four samples. Bulimina and Osangularia have opposite trends across the contact, but they diverge in the last four samples. Among planktonic genera (Table 5), Acarinina begins to decline from a maximum of $>70 \%$ below the contact, and reaches equilibrium at $\sim 20 \%$ above the contact. An inverse trend is displayed by Subbotina.

\section{Interpretation}

Data we have cited (Fig. 8) suggest that, before the hiatus, marly pelagic chalk was being relatively rapidly deposited ( $1 \mathrm{~cm} / 300 \mathrm{yr}$ ) at a well-oxygenated (low TOC; burrowing infauna; few Bolivina) epibathyal site under relatively warm bottom waters. Beginning about $10 \mathrm{~cm}$ below the contact, faunal and isotopic changes may indicate that the environment began to shift as bottom waters became even warmer. Deposition was then interrupted by a hiatus correlative with a major drop in sea level (Vail and Hardenbol, 1979; Fig. 7), during which both continental margins and abyssal sites (Thiede et al., 1981) experienced intensified erosion, and biogenic silica production was unusually high.

During the hiatus, an unknown number of erosive and nondepositional episodes took place, but the event that restarted sedimentation was a turbidity current that crossed the site, depositing its displaced components as a thin section of laminated chalk.

After the approximately 2-m.y. hiatus, the environment was quite different. Bottom water was significantly cooler, and perhaps the site was farther from the shoreline, as suggested by the decrease in terrigenous clay and relative increase in planktonic microfossils (Fig. 8). The upper water masses were also different, as reflected in the reorganized planktonic foraminiferal assemblages. The increase in globigeriniform Subbotina and the composition of the nannofossil assemblages indicate that near-surface waters were cooler (Müller, this vol.).

The displaced foraminiferal fauna is epibathyal, and, in conjunction with the pelagic nature of the sediment, suggests that the turbidity current originated on the slope not far from Site 548 .

\section{LOWER PALEOCENE/UPPER PALEOCENE UNCONFORMITY}

\section{Location, Age, Hiatus}

This intra-Paleocene unconformity is present at approximately $33 \mathrm{~cm}$ in Section 548A-28-6 (Fig. 2). At the contact, nannofossil Zone NP9 (upper Paleocene) overlies NP3 (lower Paleocene), separated by a hiatus of approximately $4 \mathrm{~m} . \mathrm{y}$.

This unconformity is clearly visible on both high-resolution and multichannel seismic reflection profiles (Figs. 3 and 4) as it truncates lower Paleocene reflections near the site and cuts into Upper Cretaceous strata just downdip from the drill site.

\section{Lithology}

\section{Visual Description}

Sediment above the contact is brown (7.5 YR 5/2-6/ 1), firm, marly (sandy and silty), upward-fining, slightly bioturbated nannofossil chalk (Fig. 2). Below the contact, sediment is nearly white (5Y $8 / 1)$, firm, sparsely burrowed, foraminiferal nannofossil chalk, mottled in shades of pale brown (10YR 8/4).

Light chalk below the contact is fractured and mixed with the dark upper chalk in a zone of mixing caused by the coring process; the original contact is probably no longer intact. Brown chalk fills burrows in the white chalk as deep as $50 \mathrm{~cm}$ below the contact. In contrast, none of the white chalk has been noticeably reworked into brown chalk above the contact.

\section{Grain Size and Mineralogy}

Grain size changes significantly across the boundary, increasing from 7.1 to $5.9 \phi$ (Table 1). Simultaneously, the percentage of montmorillonite drops from 80 to $31 \%$ (Table 2). The scale of the gamma-ray log does not permit precise identification of this intra-Paleocene unconformity, but there is a major upsection increase in intensity of 60 API units as the clay-enriched upper Paleocene and lower Eocene strata are encountered.

\section{Isotopic Analysis}

The $\delta^{18} \mathrm{O}$ and $\delta^{13} \mathrm{C}$ values become slightly greater just below the contact and decrease above it, remaining lower than the pre-hiatus values (Table 3 ).

\section{Foraminiferal Analyses}

As we have seen at the previous three unconformities, several significant faunal changes take place across the contact (Table 8). Nuttallides is clearly the most abundant single genus below the contact, but shares predominance with three other genera (Cibicides, Bulimina, Eouvigerina) in varying proportions above the contact. Generic assemblages are all typical of epibathyal Paleocene faunas.

The number of genera increases steadily upsection to the contact, and then drops back to pre-hiatus values. The percentage of benthic forms also increases slowly up to the contact, but jumps suddenly from $>2$ to $>7 \%$ above the boundary, and remains above $6 \%$.

Among individual benthic genera, the relative abundances of Eponides, Nuttallides, and Cibicides decrease slightly below the contact, and that of Stilostomella increases (Table 8). Just above the contact, Eponides, $G a$ velinella, Nuttallides, and Stilostomella decrease, and Cibicides and Gavelinella reach equilibrium at their new post-hiatus levels, but Nuttallides, Stilostomella, and Cibicides continue to fluctuate.

Planktonic genera also display distinct changes (Table 5). Turborotalia begins to increase just below the contact as Subbotina, the dominant form, steadily declines. Above the contact, Subbotina continues its steady decrease and Turborotalia disappears. Morozovella, and especially Acarinina, increase just above the boundary, but change little in the remaining upper samples, where Acarinina is predominant.

\section{Interpretation}

Data cited here (Fig. 5) suggest that, before the hiatus, nearly pure nannofossil chalk was slowly accumulating (rate indeterminate) in epibathyal depths over a 
Sections 548A-22-5 and 548A-22-6
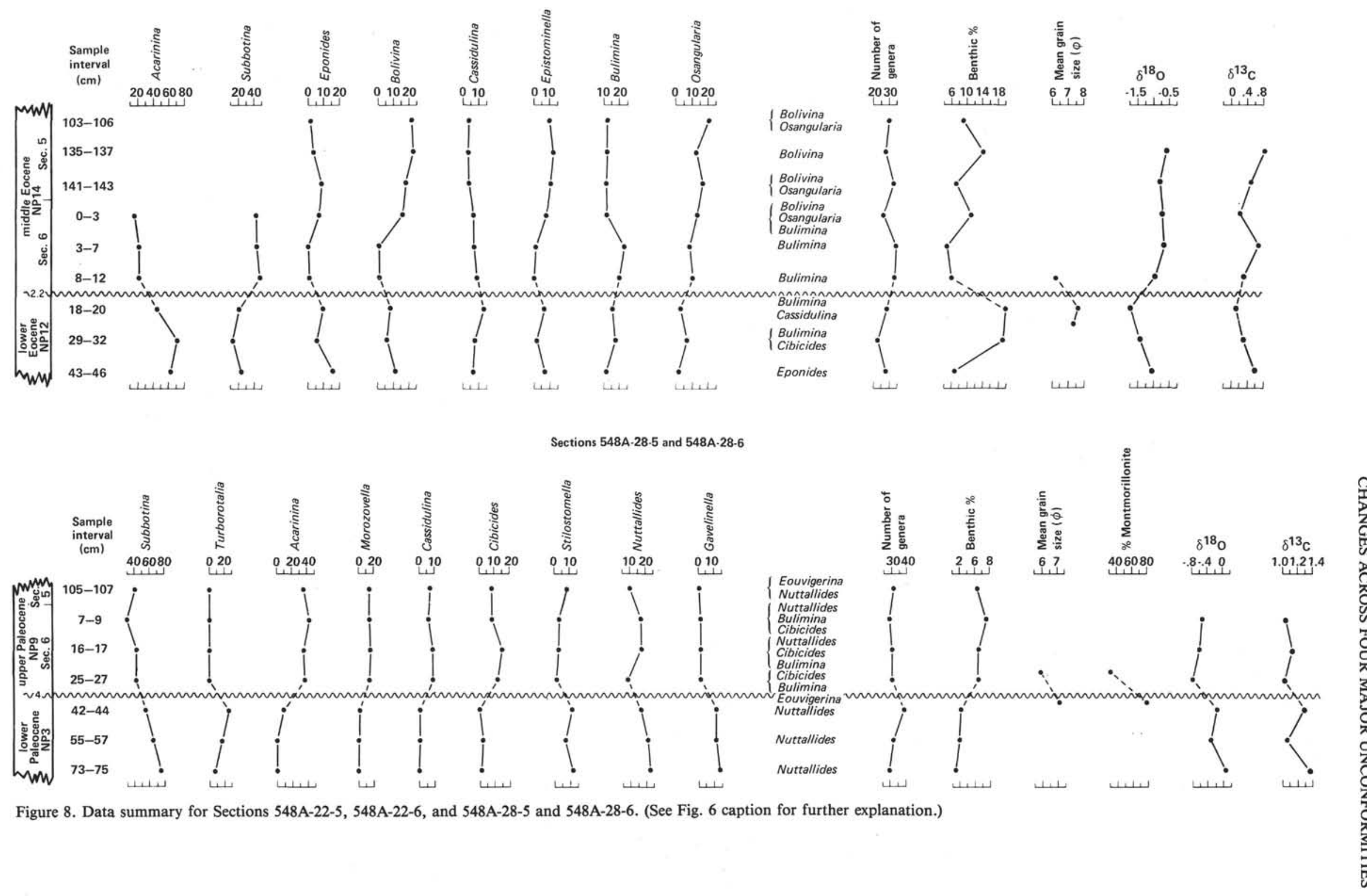
Table 8 . Census of benthic foraminiferal genera ( $\%$ of total benthic assemblage $>74 \mu \mathrm{m}$ ), Sections 548A-28-5 and 548A-28-6.

\begin{tabular}{|c|c|c|c|c|c|c|c|}
\hline \multirow[b]{2}{*}{ Genus } & \multicolumn{7}{|c|}{ Sample (interval in $\mathrm{cm}$ ) } \\
\hline & $73-75$ & $55-57$ & $42-44$ & $25-27$ & $16-17$ & $7-9$ & $105-107$ \\
\hline Bolivina & 44.7 & 5.1 & 6.5 & 3.8 & 5.8 & 3.0 & 4.6 \\
\hline Bulimina & 5.4 & 7.5 & 6.9 & 11.1 & 10.2 & 13.1 & 9.3 \\
\hline Cibicides & 1.4 & 2.4 & 0.4 & 12.5 & 15.0 & 9.3 & 8.6 \\
\hline Eouvigerina & 3.9 & 6.5 & 6.2 & 9.8 & 2.7 & 5.4 & 13.9 \\
\hline Epistominella & 0.7 & - & 0.7 & 3.8 & 4.1 & 4.8 & 6.4 \\
\hline Eponides & 2.8 & 10.2 & 8.7 & 1.0 & 1.7 & 1.5 & 1.1 \\
\hline Gavelinella & 14.0 & 11.2 & 11.3 & 0.7 & 0.3 & 1.2 & 0.4 \\
\hline Nuttallides & 22.6 & 21.4 & 16.7 & 8.4 & 18.0 & 17.3 & 10.0 \\
\hline Stilostomella & 11.5 & 6.1 & 10.2 & 1.7 & 2.4 & 3.0 & 7.0 \\
\hline Alabamina & - & - & - & - & - & 0.3 & - \\
\hline Allomorphina & - & - & - & - & 0.7 & - & - \\
\hline Anomalinoides & 0.4 & 0.7 & 2.2 & 5.6 & 2.0 & 1.2 & 1.4 \\
\hline Aragonia & 0.7 & 0.3 & 0.7 & 0.3 & - & 0.6 & - \\
\hline Astacolus & 0.4 & 0.7 & 1.1 & 0.3 & - & - & - \\
\hline Bolivinoides & - & 0.7 & 0.7 & - & - & - & - \\
\hline Bolivinopsis & - & - & 0.7 & - & - & - & - \\
\hline Buliminella & 1.1 & 1.0 & 0.4 & 0.7 & - & - & - \\
\hline Cassidulina & - & 0.3 & 0.4 & 8.7 & 8.2 & 6.6 & 6.8 \\
\hline Dentalina & 5.0 & 2.0 & 1.8 & 3.: & 3.8 & 2.1 & 1.4 \\
\hline Fissurina & 0.4 & 0.7 & - & - & - & - & - \\
\hline Fursenkoina & 7.5 & 2.4 & 1.1 & 4.2 & 1.7 & 3.3 & 3.6 \\
\hline Globobulimina & - & - & 0.7 & - & - & - & - \\
\hline Guttulina & 1.1 & 1.0 & 0.4 & - & - & - & 1.1 \\
\hline Gyroidina & 2.5 & 2.4 & 1.8 & 1.0 & 0.7 & 1.8 & 1.8 \\
\hline Heronallenia & - & - & - & 0.3 & - & 0.3 & 0.7 \\
\hline Lagena & 2.5 & 0.3 & 1.8 & 1.7 & 0.3 & 1.5 & 2.1 \\
\hline Lenticulina & 3.9 & 1.7 & 1.1 & 1.7 & 0.7 & 0.9 & 1.8 \\
\hline Loxostomum & - & - & 0.4 & - & - & - & - \\
\hline Marginulina & - & 0.7 & 1.1 & - & - & - & - \\
\hline Marssonella & - & - & 0.4 & - & - & - & - \\
\hline Melonis & - & - & 0.4 & 1.7 & 2.0 & 4.5 & - \\
\hline Oolina & 0.4 & - & 0.7 & - & 1.0 & 0.3 & 0.4 \\
\hline Oridorsalis & 0.7 & - & 0.7 & - & 0.3 & 1.2 & - \\
\hline Orthomorphina & 0.7 & 1.0 & 1.5 & - & - & - & 1.1 \\
\hline "Orthomorphina" & - & 1.7 & 2.2 & - & - & - & - \\
\hline Osangularia & 0.7 & 1.0 & 1.1 & 5.2 & 4.1 & 3.6 & 1.8 \\
\hline Pleurostomella & 0.7 & - & 0.7 & 0.3 & - & - & 0.4 \\
\hline Polymorphina & - & - & - & 0.3 & - & - & - \\
\hline Pseudouivgerina & - & - & - & - & 0.3 & 0.9 & - \\
\hline Pullenia & 0.4 & 4.1 & 3.3 & 3.8 & 2.4 & 5.7 & 1.8 \\
\hline Pulsiphonina & - & - & - & 0.7 & 1.7 & - & 1.1 \\
\hline Rosalina & - & - & - & - & - & - & 1.4 \\
\hline Seabrookia & 0.7 & - & 0.4 & - & - & - & 0.7 \\
\hline Siphotextularia & - & - & 0.4 & - & - & - & - \\
\hline Spirobolivina & - & - & - & 0.3 & 0.3 & 0.3 & - \\
\hline Tappanina & 0.7 & 2.7 & 1.8 & 4.5 & 5.4 & 4.5 & 6.1 \\
\hline Textularia & - & - & - & 0.3 & - & - & 0.4 \\
\hline Tritaxia & - & 0.3 & - & 0.3 & 0.7 & - & 1.1 \\
\hline "Tubuloaperta" & 1.4 & 2.0 & 2.5 & - & - & - & - \\
\hline Turrilina & - & - & - & - & - & 0.3 & - \\
\hline Uvigerina & - & - & - & - & - & - & 0.4 \\
\hline Valvulineria & - & 0.7 & - & - & 0.3 & - & 0.4 \\
\hline Vulvulina & - & - & - & 0.7 & 1.7 & 0.6 & 1.1 \\
\hline Total specimens & 279 & 294 & 275 & 287 & 294 & 335 & 280 \\
\hline$\%$ benthic & 1.0 & 2.0 & 2.3 & 7.3 & 7.0 & 9.3 & 6.3 \\
\hline No. of genera & 29 & 31 & 38 & 31 & 30 & 29 & 31 \\
\hline
\end{tabular}

well-oxygenated (low TOC; burrowing infauna) seafloor. Bottom waters were relatively cool, but became warmer before the hiatus. Deposition was interrupted by one or more erosive and/or nondepositional episodes that produced a hiatus of $\sim 4 \mathrm{~m}$.y. duration. This hiatal interval was a time of a major sea-level fall that produced major erosional unconformities on continental margins (Vail and Hardenbol, 1979; Fig. 7). Coevally, abyssal erosion intensified (Thiede et al., 1981), the CCD rose, and biogenic silica production was high. Moreover, a major faunal turnover in abyssal benthic foraminifers took place in the Atlantic (Tjalsma and Lohmann, 1983). In the surface waters, temperate phytoplankton migrated toward the equator (Haq, 1981). Opening of the Nor- wegian Sea may have played a causal role in these changes.

After the hiatus, initial deposition came in the form of a turbidite, which brought displaced strata from nearby on the continental slope. Bottom water was warmer, and the increase in keeled Morozovella suggests that nearsurface waters were also warmer than under pre-hiatus conditions. This is in agreement with the nannofossil assemblage, which also indicates that surface waters were warmer after the hiatus (Müller, this vol.).

\section{DISCUSSION OF ISOTOPE RESULTS}

Interpretations of isotopic analyses are tentative because so few samples were studied. Without dense sampling we cannot confidently distinguish isotopic fluctuations related to unconformities from those related to highfrequency climatic fluctuations (background). Moreover, if erosion has removed a significant section of sediment at an unconformity, the isotopic signal below the contact may not be related to the erosive event. Some important isotopic trends are notable, however. In Figure 5 we compare our average pre- and post-unconformity $\delta^{18} \mathrm{O}$ data (plotted vs. geologic age) with the limits of benthic foraminiferal $\delta^{18} \mathrm{O}$ of Savin (1977). Our results generally track with Savin's, but are consistently lighter. This probably results in part from the fact that our shallowwater site was generally warmer than the abyssal sites reported by Savin. It may also result, in part, from the fact that much of the data synthesized by Savin (1977) was produced by Shackleton: Shackleton frequently analyzes the benthic genus Uvigerina, which is $0.6 \% 0$ heavier than Cibicides, which we used. The general trend of our Miocene, Oligocene, and Eocene $\delta^{18} \mathrm{O}$ values are similar to those previously reported in the literature, but few data have documented the Paleocene decrease in $\delta^{18} \mathrm{O}$. Thus, our analyses of this interval are particularly useful.

Figure 5 also compares our $\delta^{13} \mathrm{C}$ results with those of Savin et al. (1975) and Shackleton and Kennett (1975). It is evident that the Cenozoic range of $\delta^{13} \mathrm{C}$ values is small compared with that of $\delta^{18} \mathrm{O}$, and that our results are comparable to published results. The $\delta^{13} \mathrm{C}$ results are not as useful in interpreting unconformities, because the changes are small.

\section{SUMMARY AND CONCLUSIONS}

Our analyses show that measurable, but sometimes subtle, changes in faunal, lithic, structural, and isotopic properties of the sediments take place across the unconformities examined. These changing properties reflect shifting sedimentary regimes and other environmental and climatic fluctuations. The basic sedimentary pattern established is one of a rapidly deposited turbidite resting unconformably above the eroded surface of a slowly deposited homogeneous pelagic chalk.

Combined isotopic and faunal data (Figs. 6 and 8) indicate that in each case the environment began to shift just before the hiatuses, although we cannot be sure that this shift was related to the events that actually caused the unconformity. Each unconformity, except for perhaps the Eocene one, can be detected at each of the Go- 
ban Spur sites, and can be traced widely as truncating events on the seismic profiles, documenting their regional extent. Downlapping and onlapping reflections above these seismic unconformities indicate that nondeposition also played a role in their formation. Moreover, each hiatus coincides with a major sea-level drop in the scheme of Vail and Hardenbol (1979) (Fig. 7), and also with episodes of intensified abyssal erosion at scattered sites throughout the North Atlantic (Moore et al., 1978; Thiede et al., 1981). Curiously, the Paleocene hiatus is associated with a decrease in $\delta^{18} \mathrm{O}$, suggestive of warming or of ice-volume decrease. Compared with the three younger unconformities cored in Hole 548A, this observation is inconsistent with falling sea level.

If we examine modern hydrographic conditions in the vicinity of Site 548 , we find a potential source of erosive energy that can be related directly to sea-level change. This part of Goban Spur is presently overlain by a poorly defined, oxygen-deficient, high-salinity water mass derived from the Mediterranean Sea (Mediterranean Outflow Water [MOW]; Reid, 1979; Sarnthein et al., 1982). This MOW extends downward to about $1500 \mathrm{~m}$ depth ( $\sim 300 \mathrm{~m}$ below the location of Site 548 ), where it overlies a more oxygen-rich, less saline water mass similar to North Atlantic Deep Water (NADW; Sarnthein et al., 1982). Internal waves and turbulence at water-mass boundaries such as this may cause significant erosion where the boundary intersects the seafloor (Sarnthein et al., 1982). The MOW/NADW boundary (or one similar to it) appears to have passed repeatedly up and down the Goban Spur continental slope during the Cenozoic, in concert with sea-level fluctuations (Poag and Low, this vol.), disturbing the soft sediment surface and triggering turbidity currents (Fig. 9).

Mediterranean Outflow Water seems to play an additional major role in supplying high-salinity water to the Norwegian-Greenland Sea, a critical condition for formation of NADW, and perhaps even of Antarctic Bottom Water (Reid, 1979). A major disturbance of MOW flow by sea-level rise or fall could thereby produce significant alteration of deep-sea circulation systems, bringing about coincident erosion or nondeposition at abyssal sites.

The Miocene and Paleocene hiatuses coincide with periods of increased biogenic silica production and an elevated calcite compensation depth, and in addition, all but the Oligocene hiatus are correlative with migrations of temperate nannofossil assemblages into more equatorward locations (Haq, 1980, 1981).

In the study area, faunal and isotopic data, coupled with Carla Müller's nannnofossil data, indicate that after the Miocene and Eocene hiatuses, both surface and bottom temperatures were cooler than pre-hiatus temperatures. In the Oligocene and Paleocene, post-hiatus surface and bottom temperatures were warmer (bottom temperatures also increased in the Paleocene). These circumstances suggest that a climatic change also may have been associated with each period of intensified erosion, possibly having been linked with lowered sea levels, deep circulation changes, and, in the Miocene and Oligocene, with continental ice buildup.
The results obtained indicate that our methods are productive, but also lead to recommendations for further research. The sample spacing and sample size are adequate, but as shown by the more extensive sampling in Sections 548A-22-5 and 548A-22-6, it would help to improve confidence in the trends if more samples were taken at a distance greater than 15 to $20 \mathrm{~cm}$ from the unconformable contacts. It would be especially helpful to sample above laminated strata that immediately overlie the contacts.

Faunal analyses at the generic level proved sensitive monitors of the environmental changes inferred, but further understanding of the nature of changes might be gained by examining microfossil assemblages at the species level.

We did not analyze stable isotopes in planktonic assemblages for lack of time, but such analysis would be a valuable corroborative tool for monitoring temperature changes in near-surface water masses.

One of the unexpected results of our analyses bears on the turbidity currents that brought displaced faunas to the site after each hiatus. In each case examined, the dearth of typical shelf forms such as Rosalina, Elphidium, Buccella, Hanzawaia, and Nonionella indicates that turbidite faunas were displaced from nearby slope-biotopes. This is further confirmed by similarities in the benthic foraminiferal associations across the contacts. Abundances of various genera fluctuate vertically, chiefly because of mixing and winnowing in the turbidites, but the basic generic composition of assemblages is rather constant. Here again, however, it is desirable to test this conclusion further at the species level.

\section{ACKNOWLEDGMENTS}

We thank Elazar Uchupi and Felix M. Gradstein for critically reviewing this manuscript.

\section{REFERENCES}

Berggren, W. A., 1969. Cenozoic foraminiferal faunas. In Ewing, W. M., Worzel, J. L., et al., Init. Repts. DSDP, 1: Washington (U.S. Govt. Printing Office), 594-606.

Berggren, W. A., and Aubert, J., 1975. Paleocene benthonic foraminiferal biostratigraphy, paleobiogeography and paleoecology of Atlantic-Tethyan regions: Midway-type fauna. Palaeogeogr. Palaeoclimatol. Palaeoecol., 18:73-192.

Biscaye, P. E., 1964. Distinction between kaolinite and chlorite in Recent sediments by X-ray diffraction. Am. Mineral., 49:1281-1289.

Ewing, W. M., Worzel, J. L., and Burke, C. A., 1969. Regional aspects of deep-water drilling in the Gulf of Mexico, east of Bahama Platform, and on the Bermuda Rise. In Ewing, W. M., Worzel, J. L., et al., Init. Repts. DSDP, 1: Washington (U.S. Govt. Printing Office), 624-640.

Haq, B. U., 1980. Biogeographic history of Miocene calcareous nannoplankton and paleoecology of the Atlantic Ocean. Micropaleontology, 26:414-443.

1981. Paleogene paleoceanography: early Cenozoic oceans revisited. Proc. 26th Int. Geol. Cong., Geol. Oceans Symp. (Paris), 4:71-82.

Keigwin, L. D., and Keller, G., 1984. Middle Oligocene climatic change from equatorial Pacific DSDP Site 77. Geology, 12:16-19.

Matthews, R. K., and Poore, R. Z., 1980. Tertiary $\delta^{18} \mathrm{O}$ record and glacio-eustatic sea-level fluctuations. Geology, 8:501-504.

Miller, K. G., and Tucholke, B. E., 1983. Development of Cenozoic abyssal circulation south of the Greenland-Scotland Ridge. In Bott, M., Saxov, S., Talwani, M., and Thiede, J. (Eds.), Structure and Development of the Greenland-Scotland Ridge: New York (Plenum Press), pp. 549-589. 
Moore, T. C., and Heath, G. R., 1977. Survival of deep-sea sedimentary sections. Earth Planet. Sci. Lett., 37:71-80.

Moore, T. C., van Andel, T. H., Sancetta, C., and Pisias, N. G., 1978. Cenozoic hiatuses in pelagic sediments. Micropaleontology, 24: 113-138.

Pessagno, E. A., Jr., 1969. Mesozoic planktonic foraminifera and radiolaria. In Ewing, W. M., Worzel, J. L., et al., Init. Repts. DSDP, 1: Washington (U.S. Govt. Printing Office), 607-623.

Pujos-Lamy, A., 1973. Répartition bathymètrique des foraminifères benthiques profonds du Golfe de Gascogne: comparaison avec d'autres aires océaniques. Rev. Espan. Micropaleontol. 5(2): 213-234.

Reid, J. L., 1979. On the contribution of the Mediterranean Sea outflow to the Norwegian-Greenland Sea. Deep-Sea Res., 26:1199-1223.

Rona, P. A., 1973. Worldwide unconformities in marine sediments related to eustatic changes of sea-level. Nature Phys. Sci., 244:25-26.

Sarnthein, M., Thiede, J., Pflaumann, U., Erlenkeuser, H., Fütterer, D., Koopmann, B., Lange, H., and Seibold, E., 1982. Atmospheric and oceanic circulation patterns off northwest Africa during the past 25 million years. In von Rad, U., Hinz, K., Sarnthein, M. and Seibold, E. (Eds.), Geology of the Northwest African Continental Margin: Berlin (Springer-Verlag), pp. 584-604.

Savin, S. M., 1977. The history of the earth's surface temperature during the past 100 million years. Ann. Rev. Earth Planet. Sci., 5: 319-355.

Savin, S. M., Douglas, R. G., and Stehli, F. G., 1975. Tertiary marine paleotemperatures. Geol. Soc. Am. Bull., 86:1499-1510.

Shackleton, N. J., and Kennett, J. P., 1975. Paleotemperature history of the Cenozoic and the initiation of Antarctic glaciation: oxygen and carbon isotope analyses in DSDP Sites 277,279 and 281. In Kennett, J. P., Houtz, R. E., et al., Init. Repts. DSDP, 29: Washington (U.S. Govt. Printing Office), 743-755.

Thiede, J., Agdestein, T., and Strand, J. E., 1980. Temporal and spatial variations of the upper Mesozoic and Cenozoic sediment flux to the deep North Atlantic Ocean. Mar. Geol., 36:M11-M19.

Thiede, J., Strand, J. E., and Agdestein, T., 1981. The distribution of major pelagic sediment components in the Mesozoic and Cenozoic North Atlantic Ocean. In Warme, J. E., Douglas, R. G., and Winterer, E. L. (Eds.), The Deep Sea Drilling Project: A Decade of Progress. Spec. Publ. Soc. Econ. Paleontol. Mineral., 32:67-90.

Tjalsma, R. C., and Lohmann, G. P., 1983. Paleocene-Eocene bathyal and abyssal foraminifera from the Atlantic Basin. Micropaleontology Spec. Pap., 4.
Tucholke, B. E., 1979. Relationships between acoustic stratigraphy and lithostratigraphy in the western North Atlantic Basin. In Tucholke, B. E., Vogt, P. R., et al., Init. Repts. DSDP, 43: Washington (U.S. Govt. Printing Office), 827-846.

1981. Geologic significance of seismic reflectors in the deep western North Atlantic basin. In Warme, J. E., Douglas, R. G. and Winterer, E. L. (Eds.), The Deep Sea Drilling Project: A Decade of Progress. Soc. Econ. Paleontol. Mineral. Spec. Publ., 32: 23-37.

Tucholke, B. E., and Laine, E. P., 1984. Neogene and Quaternary development of the Lower Continental Rise off the Central U.S. East Coast. In Watkins, J. S., and Drake, C. L., Studies in Continental Margin Geology, Mem. Am. Assoc. Pet. Geol., 34:295-305.

Vail, P. R., and Hardenbol, J., 1979. Sea-level changes during the Tertiary. Oceanus, 22:71-79.

Vail, P. R., and Mitchum, R. M., Jr., 1979. Global cycles of relative sea level from seismic stratigraphy. In Watkins, J. S., Montadert, L., and Dickerson, P. W. (Eds.), Geological and Geophysical Investigations of Continental Margins. Am. Assoc. Petrol. Geol. Mem., 29:469-472.

Vail, P. R., Mitchum, R. M., Jr., Shipley, T. H., and Buffler, R. T., 1980. Unconformities of the North Atlantic. Philos. Trans. $R$. Soc. London Ser. A, 294:137-155.

Vail, P. R., Mitchum, R. M., Jr., and Thompson, S., III., 1977. Seismic stratigraphy and global changes of sea level. Part Four: Global cycles of relative changes of sea level. In Payton, C. E. (Ed.), Seismic Stratigraphy-Applications to Hydrocarbon Exploration. Am. Assoc. Petrol. Geol. Mem., 26:83-98.

Vail, P. R., and Todd, R. G., 1981. Northern North Sea Jurassic unconformities, chronostratigraphy, and sea-level changes from seismic stratigraphy. In Illing, L. V., and Hobson, G. D. (Eds.), Petroleum Geology of the Continental Shelf of Northwest Europe: London (Institute of Petroleum), pp. 216-235.

Woodruff, F., Savin, S. M., and Douglas, R. G., 1981. Miocene stable isotope record: a detailed Pacific deep ocean study and its paleoclimatic implications. Science, 212:665-668.

Date of Initial Receipt: May 23, 1983

Date of Acceptance: November 22, 1983 


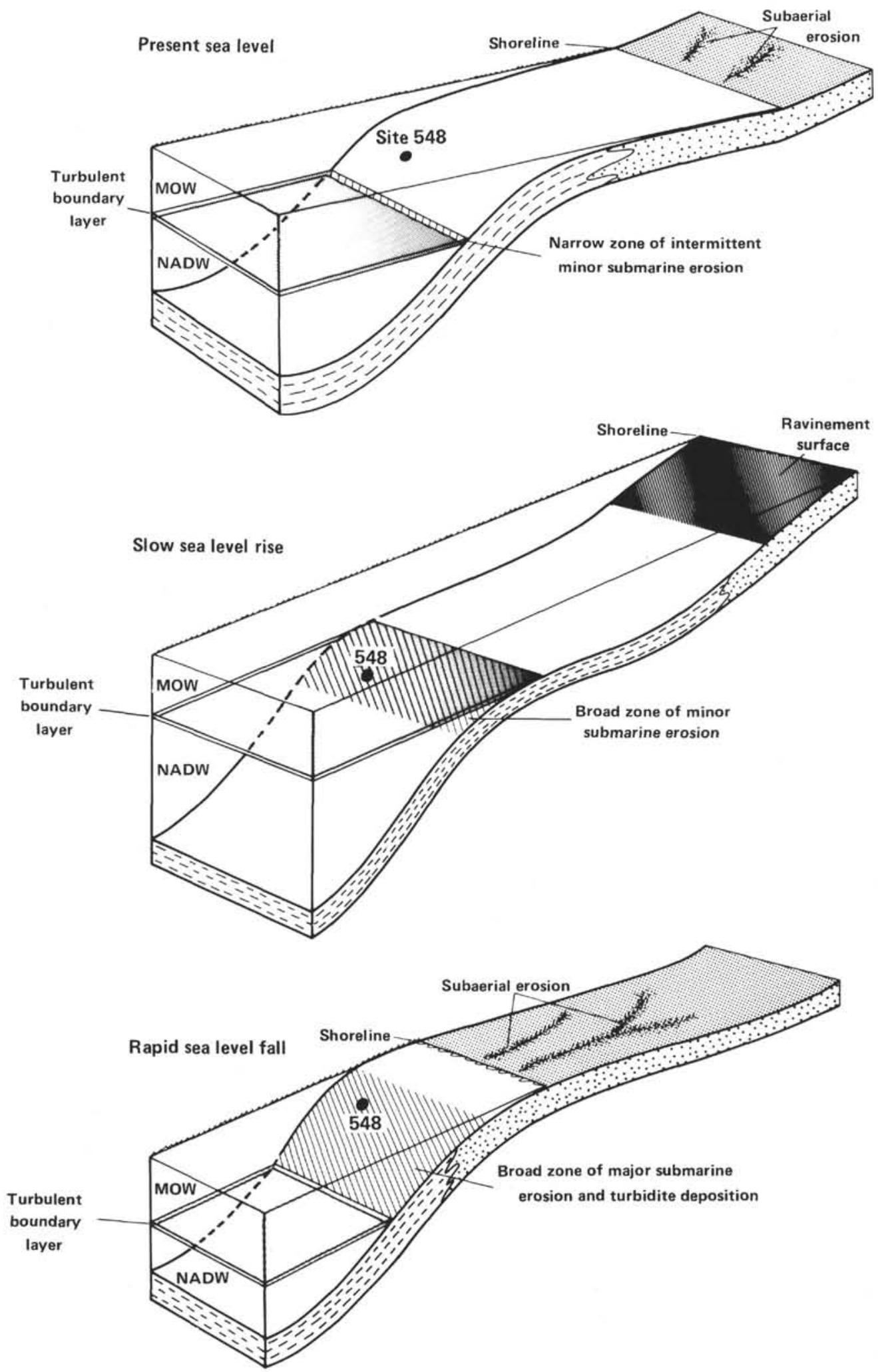

Figure 9. Schematic diagrams illustrating possible mechanisms for creating unconformities in the marine sedimentary record on the upper slope of Goban Spur and the adjacent shelf during sea-level fluctuations. MOW $=$ Mediterranean Outflow Water or similar water mass. NADW $=$ North Atlantic Deep Water or similar water mass. 